Check for updates

Cite this: Phys. Chem. Chem. Phys., 2019, 21, 2706

Received 8th November 2018, Accepted 7th January 2019

DOI: $10.1039 / c 8 c p 06950 f$

rsc.li/pccp

\section{Microhydration of protonated 5-hydroxyindole revealed by infrared spectroscopy $\dagger$}

\begin{abstract}
Johanna Klyne (D) and Otto Dopfer (D)*
Controlled microsolvation of protonated aromatic biomolecules with water is fundamental to understand proton transfer reactions in aqueous environments. We measured infrared photodissociation (IRPD) spectra of mass-selected microhydrates of protonated 5-hydroxyindole $\left(5 \mathrm{HIH}^{+}-\mathrm{W}_{n}, \mathrm{~W}=\mathrm{H}_{2} \mathrm{O}, n=1-3\right)$ in the $\mathrm{OH}$ and $\mathrm{NH}$ stretch ranges $\left(2700-3800 \mathrm{~cm}^{-1}\right)$, which are sensitive to the spectroscopic characteristics of interior solvation, water network formation, and proton transfer to solvent. Analysis of the IRPD spectra by dispersion-corrected density functional theory calculations (B3LYP-D3/aug-cc-pVTZ) reveals the coexistence of $\mathrm{C} 3$ - and C4-protonated carbenium ions, $5 \mathrm{HIH}^{+}(\mathrm{C} 3)$ and $5 \mathrm{HIH}^{+}(\mathrm{C} 4)$, as well as the $\mathrm{O}$-protonated oxonium ion, $5 \mathrm{HIH}^{+}(\mathrm{O})$. Monohydrated $5 \mathrm{HIH}^{+}-\mathrm{W}$ clusters are formed by hydrogenbonding ( $\mathrm{H}$-bonding) of the first water to the most acidic functional group, namely, the $\mathrm{NH}$ group in the case of $5 \mathrm{HIH}^{+}(\mathrm{C} 3)$, the $\mathrm{OH}$ group for $5 \mathrm{HIH}^{+}(\mathrm{C} 4)$, and the $\mathrm{OH}_{2}$ group for $5 \mathrm{HIH}^{+}(\mathrm{O})$. The latter benefits from its twofold degeneracy and the outstandingly high binding energy of $D_{0} \sim 100 \mathrm{~kJ} \mathrm{~mol}^{-1}$. Larger $5 \mathrm{HIH}^{+}-\mathrm{W}_{2 / 3}$ clusters preferably grow (i) by $\mathrm{H}$-bonding of the second water to the remaining vacant functional group and and/or (ii) by formation of $W_{2}$ water chains at the respective most acidic functional group. Our IRPD spectra of $5 \mathrm{HIH}^{+}-\mathrm{W}_{n}$ do not indicate any proton transfer to the solvent up to $n=3$, in line with the proton affinities of $5 \mathrm{HI}$ and $\mathrm{W}_{n}$. Comparison of $5 \mathrm{HIH}^{+}-\mathrm{W}_{n}$ to neutral $5 \mathrm{HI}-\mathrm{W}$ and cationic $5 \mathrm{HI}^{+}-\mathrm{W}_{n}$ clusters elucidates the impact of different charge states on the topology of the initial solvation shell. Furthermore, to access the influence of the size of the arene ion and a second functional group, we draw a comparison to microhydration of protonated phenol.
\end{abstract}

\section{Introduction}

The interaction of biomolecules, such as proteins, enzymes or hormones, with water (W) is crucial for their structure and function in living organisms. Controlled sequential microhydration of isolated biomolecules facilitates investigation of the interactions between solutes and solvents, which are blurred in the condensed phase. Infrared (IR) vibrational spectroscopy of size-selected hydrated clusters is particularly useful because it provides direct structural information. Combined with quantum chemistry, IR spectroscopy can elucidate the potential energy surface of hydration interactions.

Aromatic heterocyclic molecules are ubiquitous biomolecular building blocks. ${ }^{1-3}$ For example, 5-hydroxyindole (5HI), the prototype chosen herein, consists of pyrrole fused to a phenol ring and occurs as a subunit in the neurotransmitter serotonin. The sequential microhydration of protonated aromatic molecules is particularly interesting because proton transfer from the

Institut für Optik und Atomare Physik, Technische Universität Berlin, Hardenbergstr. 36, 10623 Berlin, Germany. E-mail: dopfer@physik.tu-berlin.de; Fax: $+49-30-31423018$

$\dagger$ Electronic supplementary information (ESI) available. See DOI: 10.1039/c8cp06950f biomolecule to the solvent may happen in these systems. Both, protonation and hydration are found to enhance the acidity of the functional groups $(\mathrm{OH} / \mathrm{NH})$, and hence their ability to donate a proton. ${ }^{4,5}$ Moreover, the proton affinity (PA) of $\mathrm{W}$ $\left(\mathrm{PA}=691 \mathrm{~kJ} \mathrm{~mol}^{-1}\right)^{6}$ and small $\mathrm{W}_{n}$ clusters $\left(\mathrm{PA}=808-879 \mathrm{~kJ} \mathrm{~mol}^{-1}\right.$ for $n=2-3)^{7,8}$ is in the same range as those of aromatic hydrocarbons (e.g., $\mathrm{PA}=750 \mathrm{~kJ} \mathrm{~mol}^{-1}$ for benzene). ${ }^{6}$ Hence, formation of a hydronium ion $\left(\mathrm{H}_{3} \mathrm{O}^{+}\right)$or protonated water clusters $\mathrm{H}^{+}\left(\mathrm{H}_{2} \mathrm{O}\right)_{n}$ via proton transfer can eventually increase the interaction energy resulting in more stable hydrated clusters. For example, protonated benzene releases its excess proton already upon hydration by a single water molecule. ${ }^{9,10}$ Moreover, for the prototypical protonated arenes (A) naphthalene and benzaldehyde, proton transfer to water occurs at cluster sizes of $n=2$ and 3 , respectively, as revealed from IR photodissociation (IRPD) spectra of their microhydrated $\left[\mathrm{A}-\mathrm{W}_{n}\right] \mathrm{H}^{+}$clusters. ${ }^{11,12}$ In general, the topology of the potential energy surface of hydrated clusters strongly depends on their charge or protonation state..$^{5,13-15}$

The microhydration of the protonated phenol $\left(\mathrm{PhH}^{+}\right)$subunit of 5HI has been studied by quantum chemistry and IRPD spectroscopy. ${ }^{14,16}$ While the theoretical study focused on the electronic structure of the carbenium ion, ${ }^{16}$ the IRPD study indicates the coexistence of ortho/para C-protonated carbenium 
and O-protonated oxonium isomers, $\mathrm{PhH}^{+}(o / p)$ and $\mathrm{PhH}^{+}(\mathrm{O})$, in a molecular beam. ${ }^{14}$ For both types of protomers, small $\mathrm{W}_{n}$ clusters are formed at the $\mathrm{OH}$ group of phenol. However, proton transfer is observed at different critical sizes of the hydration shell $\left(n_{\mathrm{c}}\right)$. While the $\mathrm{W}_{n}$ network accepts the excess proton already at $n_{\mathrm{c}}=3$ for $\mathrm{PhH}^{+}(\mathrm{O})-\mathrm{W}_{n}$, proton transfer is only possible for $n \geq 4$ in $\operatorname{PhH}^{+}(o / p)-\mathrm{W}_{n}$. This change in $n_{\mathrm{c}}$ is explained by the geometry of the carbenium cluster. The protonated $\mathrm{CH}_{2}$ group is simply too far away from the $\mathrm{W}_{n}$ network at the $\mathrm{OH}$ group. Proton transfer is possible only when the $\mathrm{W}_{n}$ cluster forms a ring bridging the $\mathrm{OH}$ and $\mathrm{CH}_{2}$ groups at $n_{\mathrm{c}}=4$. The role of binding energies $\left(D_{0}\right)$ of the $\mathrm{PhH}^{+}-\mathrm{W}_{n}$ clusters or differences in the acidity of the $\mathrm{OH}$ groups have not been discussed. However, our preceding IRPD study of the sequential microsolvation of protonated 5 -hydroxyindole $\left(5 \mathrm{HIH}^{+}\right)$by nonpolar $\mathrm{Ar}$ and quadrupolar $\mathrm{N}_{2}$ ligands (L) indicates a drastic difference in the ligand binding energies of the carbenium and oxonium protomers, $5 \mathrm{HIH}^{+}(\mathrm{C})$ and $5 \mathrm{HIH}^{+}(\mathrm{O}) .{ }^{17}$ The $5 \mathrm{HIH}^{+}-\mathrm{L}_{n}$ spectra $(n \leq 3)$ reveal the coexistence of $5 \mathrm{HIH}^{+}(\mathrm{C} 3)-\mathrm{L}_{n}$, $5 \mathrm{HIH}^{+}(\mathrm{C} 4)-\mathrm{L}_{n}$, and $5 \mathrm{HIH}^{+}(\mathrm{O})-\mathrm{L}_{n}$ clusters with ion cores protonated at $\mathrm{C} 3, \mathrm{C} 4$, and $\mathrm{O}$, respectively. This finding is surprising at first glance, because bare $5 \mathrm{HIH}^{+}(\mathrm{O})$ is drastically less stable than the carbenium ions $\left(\Delta E_{0}>100 \mathrm{~kJ} \mathrm{~mol}^{-1}\right) .^{5,17}$ The presence of clusters with an oxonium core can however be rationalized by the outstandingly large binding energies of $5 \mathrm{HIH}^{+}(\mathrm{O})-\mathrm{L}_{n}(\mathrm{OH})$ clusters with ligands attached to the $\mathrm{OH}_{2}$ group, the high barriers for isomerization from the oxonium to the carbenium ions (kinetic trapping), and the twofold degeneracy of these structures. ${ }^{14,17-20}$ Furthermore, the acidity of the $\mathrm{NH}$ and $\mathrm{OH}$ functional groups is found to strongly depend on the protonation site. ${ }^{17}$ Comparison with $\mathrm{PhH}^{+}$indicates an increase in the acidity of the $\mathrm{OH}$ group from $5 \mathrm{HIH}^{+}$to $\mathrm{PhH}^{+}{ }^{17}$ Hence, we expect intracluster proton transfer in $5 \mathrm{HIH}^{+}-\mathrm{W}_{n}$ clusters for a larger $n_{\mathrm{c}}$ value as compared to $\mathrm{PhH}^{+}-\mathrm{W}_{n}$.

To the best of our knowledge, only one theoretical study describes the microhydration of protonated $5 \mathrm{HIH}^{+}, 5$ and the protonation-induced change of the interaction potential compared to neutral hydrated clusters. This study reveals the preference of $\mathrm{OH} \cdot \cdots \mathrm{W}$ over $\mathrm{NH} \cdots \mathrm{W}$ H-bonds in the neutral ground state, in line with spectroscopic data. ${ }^{14}$ Both, $\mathrm{OH} \cdots \mathrm{W}$ and $\mathrm{NH} \cdots \mathrm{W}$ H-bonds are significantly strengthened upon protonation, ${ }^{5}$ whereas the increase in the acidity of the $\mathrm{NH}$ group is more pronounced than that of the $\mathrm{OH}$ group. As a result, the topology of the hydration shell is changed upon protonation and $\mathrm{NH} \cdots \mathrm{W}$ bonds are preferred. However, only C3-protonated $5 \mathrm{HIH}^{+}(\mathrm{C} 3)-\mathrm{W}$ clusters have been considered. ${ }^{5}$ Most likely, the topologies of $5 \mathrm{HIH}^{+}(\mathrm{C} 4)-\mathrm{W}$ and $5 \mathrm{HIH}^{+}(\mathrm{O})-\mathrm{W}$ clusters differ strongly. ${ }^{17}$ Thus, we address herein three main questions: (i) what is the protomer abundance within $5 \mathrm{HIH}^{+}-\mathrm{W}_{n}$ clusters and how is it changed compared to $5 \mathrm{HIH}^{+}-\mathrm{L}_{n}$ with $\mathrm{L}=\mathrm{Ar}$ and $\mathrm{N}_{2}$; (ii) what is the structure of the initial solvation shell in $5 \mathrm{HIH}^{+}-\mathrm{W}_{n}$; and (iii) do we observe proton transfer in the size range $n \leq 3$ and a protomer dependence of $n_{\mathrm{c}}$ ?

To this end, we analyze IRPD spectra of mass-selected hydrated clusters of $5 \mathrm{HIH}^{+}$with the aid of quantum chemical calculations. Vibrational spectroscopy in the $\mathrm{NH}$ and $\mathrm{OH}$ stretch range can determine the protonation site, discriminate interior ion solvation from water network formation, and signal potential proton transfer from $5 \mathrm{HIH}^{+}$to the $\mathrm{W}_{n}$ solvent cluster. The comparison of our results on $5 \mathrm{HIH}^{+}-\mathrm{W}$ to those obtained for $5 \mathrm{HI}^{+}-\mathrm{W}$ and $5 \mathrm{HI}-\mathrm{W}$ illustrates the influence of different charge states and protonation on the solvation of $5 \mathrm{HI}$.

\section{Experimental and computational techniques}

The microsolvation of $5 \mathrm{HIH}^{+}$is studied by IRPD spectroscopy of mass-selected $5 \mathrm{HIH}^{+}-\mathrm{W}_{n}(n=1-3)$ clusters. Additional spectra of colder $5 \mathrm{HIH}^{+}-\mathrm{W}$ are obtained by $\mathrm{Ar}$ and $\mathrm{N}_{2}$ tagging. IRPD spectra are measured in the $\mathrm{XH}$ stretch range $(\mathrm{X}=\mathrm{N}$ and $\mathrm{O}$, $2600-3800 \mathrm{~cm}^{-1}$ ) with a quadrupole-octopole-quadrupole tandem mass spectrometer described elsewhere. ${ }^{18-26}$ Briefly, protonated clusters are generated in an electron ionization source coupled to a pulsed molecular beam expansion. Solid 5HI (Sigma-Aldrich, 97\%) is heated to $145{ }^{\circ} \mathrm{C}$ and the resulting vapor is seeded in $\mathrm{Ar}$ or $\mathrm{N}_{2}$ carrier gas (8-9 bar) containing water. $\mathrm{He} / \mathrm{H}_{2}$ gas (90/10) is added to pure $\operatorname{Ar}\left(\mathrm{N}_{2}\right)$ in a 1:1 ratio to enhance the protonation efficiency. The gas mixture is expanded into vacuum through a pulsed nozzle. Close to the nozzle orifice, electron and/or chemical ionization of $\mathrm{X}$ ( $\mathrm{X}=\mathrm{Ar}, \mathrm{N}_{2}, \mathrm{H}_{2}$, or $\mathrm{W}_{n}$ ) forms $\mathrm{XH}^{+}$ions, which subsequently protonate $5 \mathrm{HI}$ via proton transfer. ${ }^{18-20,24}$ Three-body collisions with $\mathrm{W}$ and/or carrier gas molecules lead to cluster formation. In the first quadrupole, the desired parent clusters are mass-selected. Pulsed IR radiation emitted from a tunable optical parametric oscillator (2-4 mJ pulse energy, $10 \mathrm{~Hz}$ repetition rate, $1 \mathrm{~cm}^{-1}$ bandwidth) is introduced into the adjacent octopole. Resonant vibrational excitation of the parent clusters leads to the loss of the least bonded ligand, i.e. single $\mathrm{W}$ molecules in the case of $5 \mathrm{HIH}^{+}-$ $\mathrm{W}_{n}$ or the loosely bound $\mathrm{Ar} / \mathrm{N}_{2}$ tag for $5 \mathrm{HIH}^{+}-\mathrm{W}-\mathrm{Ar} / \mathrm{N}_{2}$. The produced fragment ions are mass-selected with the second quadrupole and monitored by a Daly detector as a function of the IR laser frequency to derive the IRPD spectrum of the $5 \mathrm{HIH}^{+}-\mathrm{W}_{n}$ or $5 \mathrm{HIH}^{+}-\mathrm{W}-\mathrm{Ar} / \mathrm{N}_{2}$ parent clusters. The ion source is triggered at $20 \mathrm{~Hz}$ (twice the laser frequency) facilitating subtraction of the background signal (metastable decay). All IRPD spectra are normalized for laser intensity variations recorded with a pyroelectric detector. Collision-induced dissociation in the octopole confirms the composition of mass-selected parent clusters. ${ }^{22,23}$

The protonation sites in $5 \mathrm{HIH}^{+}$have already been examined in a previous study. ${ }^{17}$ The $5 \mathrm{HIH}^{+}$protomers offer two competing $\mathrm{H}$-bonding sites for $\mathrm{W}$ molecules, namely, their $\mathrm{NH}$ and $\mathrm{OH}$ functional groups. The $5 \mathrm{HIH}^{+}-\mathrm{W}_{n}$ input structures for geometry optimization are constructed by hand, attaching $\mathrm{W}$ ligands successively to the $\mathrm{NH}$ and $\mathrm{OH}$ groups. Up to $n=3$, this approach is still feasible to find all low-energy minima. For larger hydrates (and more flexible organic chromophores), it may be rather difficult to find geometries by hand and, as a consequence, systematic computational sampling techniques such as basin-hopping or molecular dynamics should be employed. ${ }^{28-30}$ Geometries, energies, and harmonic IR spectra of stable $5 \mathrm{HIH}^{+}-\mathrm{W}_{n}(n=1-3)$ and $5 \mathrm{HIH}^{+}-\mathrm{W}-\mathrm{Ar} / \mathrm{N}_{2}$ (ESI $\left.\dagger\right)$ structures are calculated at the B3LYP-D3/aug-cc-pVTZ level using GAUSSIAN09. ${ }^{27,31-34}$ This hybrid density functional with 
additive dispersion correction has proven to yield reliable results for related aromatic clusters. ${ }^{11,22,23,35-39}$ For example, the binding energies computed for the monohydrates of the benzene and naphthalene cations $\left(D_{0}=3209\right.$ and $\left.2773 \mathrm{~cm}^{-1}\right)$ compare favorably with the experimental values $\left(D_{0}=3290 \pm\right.$ 120 and $\left.2800 \pm 300 \mathrm{~cm}^{-1}\right) .{ }^{40,41}$ Similarly, the calculated binding energy of $\mathrm{W}_{2}\left(D_{0}=1108 \mathrm{~cm}^{-1}\right)$ matches the measured value $\left(D_{0}=1105 \pm 10 \mathrm{~cm}^{-1}\right) \cdot{ }^{42,43}$ We optimize selected structures also at the PBE0-D3/aug-cc-pVTZ level to yield reference data on structural and spectroscopic properties. The PBE0 functional is frequently used to compute properties of molecular clusters and is less empirical than B3LYP. ${ }^{28,30,44-46}$ Furthermore, singlepoint energy calculations of selected optimized structures are performed at the CC2/aug-cc-pVDZ level. Comparison to neutral and cationic $s / a 5 \mathrm{HI}-\mathrm{W}$ clusters previously studied at the same level (B3LYP-D3/aug-cc-pVTZ) yields the effects of protonation. ${ }^{22,23}$ Total binding energies $\left(D_{0}\right)$ are derived by subtracting the zeropoint corrected energies of the corresponding monomers from that of the cluster: $D_{0}=E_{0}\left(5 \mathrm{HIH}^{+}-\mathrm{W}_{n}\right)-E_{0}\left(5 \mathrm{HIH}^{+}\right)-n \cdot E_{0}(\mathrm{~W})$. Binding energies of the $\mathrm{Ar} / \mathrm{N}_{2}$ tag in $5 \mathrm{HIH}^{+}-\mathrm{W}-\mathrm{Ar} / \mathrm{N}_{2}$ are calculated in a similar way. For selected structures, we estimate the basis set superposition errors (BSSE) using the counterpoise method. ${ }^{47,48}$ Calculated harmonic vibrational frequencies are linearly scaled by a factor of 0.957 derived previously from fitting the free $\mathrm{OH}$ stretching frequency of cationic $s / a 5 \mathrm{HI}^{+}{ }^{22}$ Yet, this scaling factor yields $\mathrm{OH}$ stretch frequencies of $\mathrm{W}\left(\nu_{1 / 3}=3635 /\right.$ $3733 \mathrm{~cm}^{-1}$ ) systematically lower by $\sim 20 \mathrm{~cm}^{-1}$ than the experimental values $\left(\nu_{1 / 3}=3657 / 3756 \mathrm{~cm}^{-1}\right) .{ }^{49}$ For selected $5 \mathrm{HIH}^{+}-\mathrm{W}$ clusters, anharmonic spectra are calculated at the B3LYP-D3/ aug-cc-pVDZ level as implemented in GAUSSIAN09. ${ }^{50}$

\section{Results and discussion}

\subsection{IRPD spectra}

An overview of the IRPD spectra of $5 \mathrm{HIH}^{+}-\mathrm{W}_{n}$ with $n=1-3$ measured in the $\mathrm{XH}$ stretch range is given in Fig. 1. The positions, widths, and suggested vibrational and isomer assignments of the transitions observed (A-L, X) are listed in Table 1, along with computed frequencies and IR oscillator strengths. The spectra cover the antisymmetric and symmetric $\mathrm{OH}$ stretching modes of water ( $\nu_{3}$ and $\nu_{1}$, bands $\mathrm{A}$ and $\mathrm{B}$ ) and the $\mathrm{OH}$ and $\mathrm{NH}$ stretching modes of $5 \mathrm{HIH}^{+}\left(\nu_{\mathrm{OH}}\right.$ and $\left.\nu_{\mathrm{NH}}\right)$. Dotted lines indicate the correspondence of related bands in the different spectra. Bands $\mathrm{G}$ and $\mathrm{H}$ emerging in the spectra of $5 \mathrm{HIH}^{+}-\mathrm{W}_{n}$ with $n \geq 2$ already indicate the formation of a H-bonded water network. In the following, the IRPD spectra are disentangled by comparison with IR spectra calculated for the possible isomers and taking into account the previous interpretation of the $5 \mathrm{HIH}^{+}-\mathrm{L}_{n}$ spectra with $\mathrm{L}=\mathrm{Ar}$ and $\mathrm{N}_{2} \cdot{ }^{17}$ IRPD spectra of tagged $5 \mathrm{HIH}^{+}-\mathrm{W}-\mathrm{L}$ clusters with $\mathrm{L}=\mathrm{Ar}$ and $\mathrm{N}_{2}$ are shown in Fig. S1 in the ESI. $\dagger$

\section{$3.25 \mathrm{HIH}^{+}-\mathrm{W}$}

Internal $\mathrm{OH}$ rotation yields syn and anti rotamers of $5 \mathrm{HIH}^{+}$, denoted by $s 5 \mathrm{HIH}^{+}$and $a 5 \mathrm{HIH}^{+}$, respectively. Our previous study of $5 \mathrm{HIH}^{+}-\mathrm{L}_{n}$ demonstrates the coexistence of the most

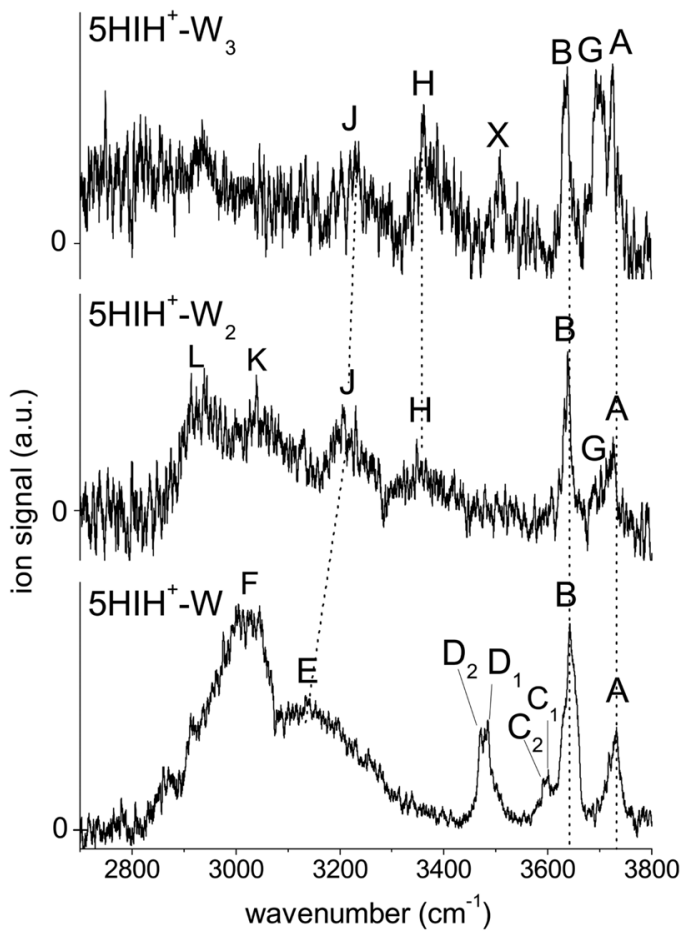

Fig. 1 Overview of the IRPD spectra of $5 \mathrm{HIH}^{+}-\mathrm{W}_{n}(n=1-3)$ measured in the $\mathrm{XH}$ stretch range $\left(2700-3800 \mathrm{~cm}^{-1}\right)$. The positions, widths, and vibrational and isomer assignments of the transitions are listed in Table 1.

stable $s / a 5 \mathrm{HIH}^{+}(\mathrm{C} 3)$ protomers $\left(\Delta E_{0}=0 / 1.8 \mathrm{~kJ} \mathrm{~mol}^{-1}\right)$, as well as the $s / a 5 \mathrm{HIH}^{+}(\mathrm{C} 4)$ and $s / a 5 \mathrm{HIH}^{+}(\mathrm{O})$ isomers $\left(\Delta E_{0}=5.1 / 11.1\right.$ and $\left.117.1 / 117.7 \mathrm{~kJ} \mathrm{~mol}^{-1}\right) .{ }^{17}$ With the exception of $5 \mathrm{HIH}^{+}(\mathrm{C} 4)$, the syn and anti rotamers of the $5 \mathrm{HIH}^{+}$protomers have similar energies and IR spectra and thus cannot be distinguished at the current spectral resolution. A deep potential well $\left(\Delta E>150 \mathrm{~kJ} \mathrm{~mol}^{-1}\right)$ prevents the interconversion of the drastically less stable $5 \mathrm{HIH}^{+}(\mathrm{O})$ isomers into $5 \mathrm{HIH}^{+}(\mathrm{C} 4) .{ }^{17}$ We compute proton affinities (PAs) of 905/902 $\mathrm{kJ} \mathrm{mol}^{-1}$ for $s / a 5 \mathrm{HIH}^{+}(\mathrm{C} 3), 900 / 892 \mathrm{~kJ} \mathrm{~mol}^{-1}$ for $s / a 5 \mathrm{HIH}^{+}(\mathrm{C} 4)$, and $786 / 785 \mathrm{~kJ} \mathrm{~mol}^{-1}$ for $s / a 5 \mathrm{HIH}^{+}(\mathrm{O}) .{ }^{17}$ On the other hand, for $\mathrm{W}_{n}$ clusters we calculate PAs of 681,818 , and $898 \mathrm{~kJ} \mathrm{~mol}^{-1}$ for $n=1-3$, respectively. Hence, the predicted PA of $s / a 5 \mathrm{HIH}^{+}(\mathrm{O})$ is smaller than that of the $\mathrm{W}_{n}$ cluster already at $n=2$, and the proton may be transferred from this $5 \mathrm{HIH}^{+}$protomer to the $\mathrm{W}_{n}$ solvent cluster. The PAs of $s / a 5 \mathrm{HIH}^{+}(\mathrm{C} 3 / \mathrm{C} 4)$ are in the same range as that of the $\mathrm{W}_{3}$ cluster. Yet, proton transfer may still occur if the solvation energy of the protontransferred structure is higher. Due to the possible proton transfer to the $\mathrm{W}_{n}$ moiety, the notation $\left[5 \mathrm{HI}-\mathrm{W}_{n}\right] \mathrm{H}^{+}$is more precise. However, for consistency, we keep the $5 \mathrm{HIH}^{+}-\mathrm{W}_{n}$ notation for all clusters throughout this paper. Based on our previous results, ${ }^{17}$ we calculate herein hydrated clusters of $s / a 5 \mathrm{HIH}^{+}(\mathrm{C} 3), s / a 5 \mathrm{HIH}^{+}(\mathrm{C} 4)$, and $s / a 5 \mathrm{HIH}^{+}(\mathrm{O})$ with $\mathrm{W}$ attached to the acidic functional $\mathrm{OH}_{(2)}$ and $\mathrm{NH}$ groups, the $\pi$-electron cloud, or the protonated $\mathrm{CH}_{2}$ group. In general, the binding motifs are very similar for the syn and anti rotamers of the $5 \mathrm{HIH}^{+}-\mathrm{W}_{n}$ clusters, with $s 5 \mathrm{HIH}^{+}-\mathrm{W}_{n}$ being systematically more stable (Table S1, ESI $\dagger$ ). Therefore, in the main text and 
Table 1 Positions (in $\mathrm{cm}^{-1}$ ) and widths (FWHM, in parentheses) of the bands observed in the IRPD spectra of 5HIH+ $-\mathrm{W}_{n}(n=1-3)(\mathrm{Fig} .1) \mathrm{compared}$ to scaled harmonic frequencies (in cm ${ }^{-1}$ ) and IR intensities ( $\mathrm{km} \mathrm{mol}^{-1}$, in parentheses) of the assigned s5HIH $\mathrm{H}^{+}-\mathrm{W}_{n}$ isomers calculated at the B3LYP-D3/augcc-pVTZ level. Vibrational frequencies of the corresponding $a 5 \mathrm{HIH}^{+}-\mathrm{W}_{n}$ clusters are listed in Table S1 (ESI)

\begin{tabular}{|c|c|c|c|c|}
\hline Cluster & Exp. & Vibration & Calc. & Isomer \\
\hline \multirow[t]{16}{*}{$5 \mathrm{HIH}^{+}-\mathrm{W}$} & \multirow[t]{4}{*}{ A $3732(30)$} & $\nu_{3}$ & 3704 (119) & $s 5 \mathrm{HIH}^{+}(\mathrm{C} 3)-\mathrm{W}(\mathrm{NH})$ \\
\hline & & $\nu_{3}$ & $3708(118)$ & $s 5 \mathrm{HIH}^{+}(\mathrm{C} 4)-\mathrm{W}(\mathrm{NH})$ \\
\hline & & $\nu_{3}$ & $3697(134)$ & $s 5 \mathrm{HIH}^{+}(\mathrm{C} 4)-\mathrm{W}(\mathrm{OH})$ \\
\hline & & $\nu_{3}$ & $3685(178)$ & $s 5 \mathrm{HIH}^{+}(\mathrm{O})-\mathrm{W}(\mathrm{OH})$ \\
\hline & \multirow[t]{5}{*}{ B 3641 (25) } & $\nu_{\mathrm{OH}}^{\mathrm{f}}$ & $3632(164)$ & $s 5 \mathrm{HIH}^{+}(\mathrm{C} 3)-\mathrm{W}(\mathrm{NH})$ \\
\hline & & $\nu_{1}$ & $3622(54)$ & $s 5 \mathrm{HIH}^{+}(\mathrm{C} 3)-\mathrm{W}(\mathrm{NH})$ \\
\hline & & $\nu_{1}$ & $3612(52)$ & $s 5 \mathrm{HIH}^{+}(\mathrm{C} 4)-\mathrm{W}(\mathrm{OH})$ \\
\hline & & $\nu_{1}$ & $3622(40)$ & $s 5 \mathrm{HIH}^{+}(\mathrm{C} 4)-\mathrm{W}(\mathrm{NH})$ \\
\hline & & $\nu_{1}$ & $3600(68)$ & $s 5 \mathrm{HIH}^{+}(\mathrm{O})-\mathrm{W}(\mathrm{OH})$ \\
\hline & $\mathbf{C}_{1} 3600(5)$ & $\nu_{\mathrm{OH}}^{\mathrm{f}}$ & $3588(219)$ & $s 5 \mathrm{HIH}^{+}(\mathrm{C} 4)-\mathrm{W}(\mathrm{NH})$ \\
\hline & $\mathbf{C}_{2} 3591(5)$ & $\nu_{\mathrm{OH}}^{\mathrm{f}}$ & 3558 (199) & $s 5 \mathrm{HIH}^{+}(\mathrm{O})-\mathrm{W}(\mathrm{OH})$ \\
\hline & $\mathbf{D}_{1} 3485(30)$ & $\nu_{\mathrm{NH}}^{\mathrm{f}}$ & 3494 (116) & $s 5 \mathrm{HIH}^{+}(\mathrm{O})-\mathrm{W}(\mathrm{OH})$ \\
\hline & $\mathbf{D}_{2} 3470(30)$ & $\nu_{\mathrm{NH}}^{\mathrm{f}}$ & 3478 (139) & $s 5 \mathrm{HIH}^{+}(\mathrm{C} 4)-\mathrm{W}(\mathrm{OH})$ \\
\hline & E $3130(100)$ & $\nu_{\mathrm{NH}}^{\mathrm{b}}$ & $3191(1184)$ & $s 5 \mathrm{HIH}^{+}(\mathrm{C} 4)-\mathrm{W}(\mathrm{NH})$ \\
\hline & \multirow[t]{2}{*}{ F $3015(70)$} & $\nu_{\mathrm{OH}}^{\mathrm{b}}$ & $3035(2283)$ & $s 5 \mathrm{HIH}^{+}(\mathrm{C} 4)-\mathrm{W}(\mathrm{OH})$ \\
\hline & & $\nu_{\mathrm{NH}}^{\mathrm{b}}$ & 3011 (1399) & $s 5 \mathrm{HIH}^{+}(\mathrm{C} 3)-\mathrm{W}(\mathrm{NH})$ \\
\hline \multirow[t]{13}{*}{$5 \mathrm{HIH}^{+}-\mathrm{W}_{2}$} & \multirow[t]{3}{*}{ A 3725 (20) } & $\nu_{3}$ & $3711(131) / 3707$ (113) & $s 5 \mathrm{HIH}^{+}(\mathrm{C} 3)-\mathrm{W}_{2}(\mathrm{NH}-\mathrm{OH})$ \\
\hline & & $\nu_{3}$ & $3717(114)$ & $s 5 \mathrm{HIH}^{+}(\mathrm{C} 3)-\mathrm{W}_{2}(\mathrm{NH}-\mathrm{W})$ \\
\hline & & $\nu_{3}$ & $3711(114) / 3700(128)$ & $s 5 \mathrm{HIH}^{+}(\mathrm{C} 4)-\mathrm{W}_{2}(\mathrm{NH}-\mathrm{OH})$ \\
\hline & G $3692(10)$ & $\nu_{\mathrm{OH}}^{\mathrm{f}(\mathrm{W})}$ & $3690(105)$ & $s 5 \mathrm{HIH}^{+}(\mathrm{C} 3)-\mathrm{W}_{2}(\mathrm{NH}-\mathrm{W})$ \\
\hline & \multirow[t]{3}{*}{ B 3638 (15) } & $\nu_{1}$ & $3624(49) / 3619(33)$ & $s 5 \mathrm{HIH}^{+}(\mathrm{C} 3)-\mathrm{W}_{2}(\mathrm{NH}-\mathrm{OH})$ \\
\hline & & $\nu_{\mathrm{OH}}^{\mathrm{f}}$ & $3635(156)$ & $s 5 \mathrm{HIH}^{+}(\mathrm{C} 3)-\mathrm{W}_{2}(\mathrm{NH}-\mathrm{W})$ \\
\hline & & $\nu_{1}$ & $3624(37) / 3615(48)$ & $s 5 \mathrm{HIH}^{+}(\mathrm{C} 4)-\mathrm{W}_{2}(\mathrm{NH}-\mathrm{OH})$ \\
\hline & \multirow[t]{2}{*}{ H $3348(>50)$} & $\nu_{\mathrm{OH}}^{\mathrm{b}}$ & $3283(1565)$ & $s 5 \mathrm{HIH}^{+}(\mathrm{C} 3)-\mathrm{W}_{2}(\mathrm{NH}-\mathrm{OH})$ \\
\hline & & $\nu_{\mathrm{OH}}^{\mathrm{b}(\mathrm{W})}$ & $3308(921)$ & $s 5 \mathrm{HIH}^{+}(\mathrm{C} 3)-\mathrm{W}_{2}(\mathrm{NH}-\mathrm{W})$ \\
\hline & J $3205(>50)$ & $\nu_{\mathrm{NH}}^{\mathrm{b}}$ & $3218(1094)$ & $s 5 \mathrm{HIH}^{+}(\mathrm{C} 4)-\mathrm{W}_{2}(\mathrm{NH}-\mathrm{OH})$ \\
\hline & \multirow[t]{2}{*}{ K $3040(>50)$} & $\nu_{\mathrm{NH}}^{\mathrm{b}}$ & 3041 (1331) & $s 5 \mathrm{HIH}^{+}(\mathrm{C} 3)-\mathrm{W}_{2}(\mathrm{NH}-\mathrm{OH})$ \\
\hline & & $\nu_{\mathrm{OH}}^{\mathrm{b}}$ & $3083(2234)$ & $s 5 \mathrm{HIH}^{+}(\mathrm{C} 4)-\mathrm{W}_{2}(\mathrm{NH}-\mathrm{OH})$ \\
\hline & L $2940(>50)$ & $\nu_{\mathrm{NH}}^{\mathrm{b}}$ & 2787 (2249) & $s 5 \mathrm{HIH}^{+}(\mathrm{C} 3)-\mathrm{W}_{2}(\mathrm{NH}-\mathrm{W})$ \\
\hline \multirow[t]{32}{*}{$5 \mathrm{HIH}^{+}-\mathrm{W}_{3}$} & \multirow[t]{7}{*}{ A $3725(20)$} & $\nu_{3}$ & $3719(112) / 3708$ (114) & $s 5 \mathrm{HIH}^{+}(\mathrm{C} 3)-\mathrm{W}_{3}(\mathrm{OH}-\mathrm{NH}-\mathrm{W})$ \\
\hline & & $\nu_{3}$ & $3721(111)$ & $s 5 \mathrm{HIH}^{+}(\mathrm{C} 3)-\mathrm{W}_{3}(\mathrm{NH}-\mathrm{W}-\mathrm{W})$ \\
\hline & & $\nu_{3}$ & $3722(208)$ & $s 5 \mathrm{HIH}^{+}(\mathrm{C} 3)-\mathrm{W}_{3}(\mathrm{~W}-\mathrm{NH}-\mathrm{W})$ \\
\hline & & $\nu_{3}$ & $3723(106) / 3702(127)$ & $s 5 \mathrm{HIH}^{+}(\mathrm{C} 4)-\mathrm{W}_{3}(\mathrm{OH}-\mathrm{NH}-\mathrm{W})$ \\
\hline & & $\nu_{3}$ & $3722(115) / 3712(112)$ & $s 5 \mathrm{HIH}^{+}(\mathrm{C} 4)-\mathrm{W}_{3}(\mathrm{OH}-\mathrm{W}-\mathrm{NH})$ \\
\hline & & $\nu_{3}$ & $3702(147) / 3695(222)$ & $s 5 \mathrm{HIH}^{+}(\mathrm{O})-\mathrm{W}_{3}(\mathrm{NH}-\mathrm{OH}-\mathrm{W} 1)$ \\
\hline & & $\nu_{3}$ & $3717(128) / 3704(143)$ & $s 5 \mathrm{HIH}^{+}(\mathrm{O})-\mathrm{W}_{3}(\mathrm{NH}-\mathrm{OH}-\mathrm{W} 2)$ \\
\hline & \multirow[t]{7}{*}{ G $3692(30)$} & $\nu_{\mathrm{OH}}^{\mathrm{f}}$ & $3692(102)$ & $s 5 \mathrm{HIH}^{+}(\mathrm{C} 3)-\mathrm{W}_{3}(\mathrm{OH}-\mathrm{NH}-\mathrm{W})$ \\
\hline & & $\nu_{\mathrm{OH}}^{\mathrm{f}(\mathrm{W})}$ & $3694(70)$ & $s 5 \mathrm{HIH}^{+}(\mathrm{C} 3)-\mathrm{W}_{3}(\mathrm{NH}-\mathrm{W}-\mathrm{W})$ \\
\hline & & $\nu_{\mathrm{OH}}^{\mathrm{f}(\mathrm{W})}$ & $3693(111)$ & $s 5 \mathrm{HIH}^{+}(\mathrm{C} 3)-\mathrm{W}_{3}(\mathrm{NH}-\mathrm{W}-\mathrm{W})$ \\
\hline & & $\nu_{\mathrm{OH}}^{\mathrm{f}(\mathrm{W})}$ & $3689(92)$ & $s 5 \mathrm{HIH}^{+}(\mathrm{C} 4)-\mathrm{W}_{3}(\mathrm{OH}-\mathrm{NH}-\mathrm{W})$ \\
\hline & & $\nu_{\mathrm{OH}}^{\mathrm{f}(\mathrm{W})}$ & $3679(100)$ & $s 5 \mathrm{HIH}^{+}(\mathrm{C} 4)-\mathrm{W}_{3}(\mathrm{OH}-\mathrm{W}-\mathrm{NH})$ \\
\hline & & $\nu_{\mathrm{OH}}^{\mathrm{fH}(\mathrm{W})}$ & $3661(140)$ & $s 5 \mathrm{HIH}^{+}(\mathrm{O})-\mathrm{W}_{3}(\mathrm{NH}-\mathrm{OH}-\mathrm{W} 1)$ \\
\hline & & $\nu_{\mathrm{OH}}^{\mathrm{f}(\mathrm{W})}$ & $3677(97)$ & $s 5 \mathrm{HIH}^{+}(\mathrm{O})-\mathrm{W}_{3}(\mathrm{NH}-\mathrm{OH}-\mathrm{W} 2)$ \\
\hline & \multirow[t]{9}{*}{ B $3637(20)$} & $\nu_{1}$ & $3630(27) / 3620(31)$ & $s 5 \mathrm{HIH}^{+}(\mathrm{C} 3)-\mathrm{W}_{3}(\mathrm{OH}-\mathrm{NH}-\mathrm{W})$ \\
\hline & & $\nu_{\mathrm{OH}}^{\mathrm{f}(\mathrm{W})}$ & $3635(151)$ & $s 5 \mathrm{HIH}^{+}(\mathrm{C} 3)-\mathrm{W}_{3}(\mathrm{NH}-\mathrm{W}-\mathrm{W})$ \\
\hline & & $\nu_{1}$ & $3631(23)$ & $s 5 \mathrm{HIH}^{+}(\mathrm{C} 3)-\mathrm{W}_{3}(\mathrm{NH}-\mathrm{W}-\mathrm{W})$ \\
\hline & & $\nu_{\mathrm{OH}}^{\mathrm{f}}$ & $3636(147)$ & $s 5 \mathrm{HIH}^{+}(\mathrm{C} 3)-\mathrm{W}_{3}(\mathrm{~W}-\mathrm{NH}-\mathrm{W})$ \\
\hline & & $\nu_{1}$ & $3631(29)$ & $s 5 \mathrm{HIH}^{+}(\mathrm{C} 3)-\mathrm{W}_{3}(\mathrm{~W}-\mathrm{NH}-\mathrm{W})$ \\
\hline & & $\nu_{1}$ & $3632(24) / 3616(45)$ & $s 5 \mathrm{HIH}^{+}(\mathrm{C} 4)-\mathrm{W}_{3}(\mathrm{OH}-\mathrm{NH}-\mathrm{W})$ \\
\hline & & $\nu_{1}$ & $3631(29) / 3624(35)$ & $s 5 \mathrm{HIH}^{+}(\mathrm{C} 4)-\mathrm{W}_{3}(\mathrm{OH}-\mathrm{W}-\mathrm{NH})$ \\
\hline & & $\nu_{1}$ & $3616(54) / 3586(100)$ & $s 5 \mathrm{HIH}^{+}(\mathrm{O})-\mathrm{W}_{3}(\mathrm{NH}-\mathrm{OH}-\mathrm{W} 1)$ \\
\hline & & $\nu_{1}$ & $3628(36) / 3617(45)$ & $s 5 \mathrm{HIH}^{+}(\mathrm{O})-\mathrm{W}_{3}(\mathrm{NH}-\mathrm{OH}-\mathrm{W} 2)$ \\
\hline & \multirow[t]{2}{*}{ X $3508(30)$} & $\nu_{\mathrm{NH}}^{\mathrm{f}}$ & $3497(108)$ & $s 5 \mathrm{HIH}^{+}(\mathrm{O})-\mathrm{W}_{3}(\mathrm{NH}-\mathrm{OH}-\mathrm{W} 1)$ \\
\hline & & $\nu_{\mathrm{NH}}^{\mathrm{f}}$ & $3500(105)$ & $s 5 \mathrm{HIH}^{+}(\mathrm{O})-\mathrm{W}_{3}(\mathrm{NH}-\mathrm{OH}-\mathrm{W} 2)$ \\
\hline & \multirow[t]{7}{*}{ H $3360(>50)$} & $\nu_{\mathrm{OH}}^{\mathrm{b}(\mathrm{W})}$ & $3375(723)$ & $s 5 \mathrm{HIH}^{+}(\mathrm{C} 4)-\mathrm{W}_{3}(\mathrm{OH}-\mathrm{NH}-\mathrm{W})$ \\
\hline & & $\nu_{\mathrm{OH}}^{\mathrm{b}(\mathrm{W})}$ & $3306(891)$ & $s 5 \mathrm{HIH}^{+}(\mathrm{C} 4)-\mathrm{W}_{3}(\mathrm{OH}-\mathrm{W}-\mathrm{NH})$ \\
\hline & & $\nu_{\mathrm{OH}}^{\mathrm{b}(\mathrm{W})}$ & $3326(867)$ & $s 5 \mathrm{HIH}^{+}(\mathrm{C} 3)-\mathrm{W}_{3}(\mathrm{OH}-\mathrm{NH}-\mathrm{W})$ \\
\hline & & $\nu_{\mathrm{OH}}^{\mathrm{b}}$ & $3301(156)$ & $s 5 \mathrm{HIH}^{+}(\mathrm{C} 3)-\mathrm{W}_{3}(\mathrm{OH}-\mathrm{NH}-\mathrm{W})$ \\
\hline & & $\nu_{\mathrm{OH}}^{\mathrm{b}(\mathrm{W})}$ & $3378(663)$ & $s 5 \mathrm{HIH}^{+}(\mathrm{C} 3)-\mathrm{W}_{3}(\mathrm{NH}-\mathrm{W}-\mathrm{W})$ \\
\hline & & $\nu_{\mathrm{OH}}^{\mathrm{b}(\mathrm{as})}$ & $3424(380)$ & $s 5 \mathrm{HIH}^{+}(\mathrm{C} 3)-\mathrm{W}_{3}(\mathrm{~W}-\mathrm{NH}-\mathrm{W})$ \\
\hline & & $\nu_{\mathrm{OH}}^{\mathrm{b}(\mathrm{s})}$ & $3381(516)$ & $s 5 \mathrm{HIH}^{+}(\mathrm{C} 3)-\mathrm{W}_{3}(\mathrm{~W}-\mathrm{NH}-\mathrm{W})$ \\
\hline
\end{tabular}


Table 1 (continued)

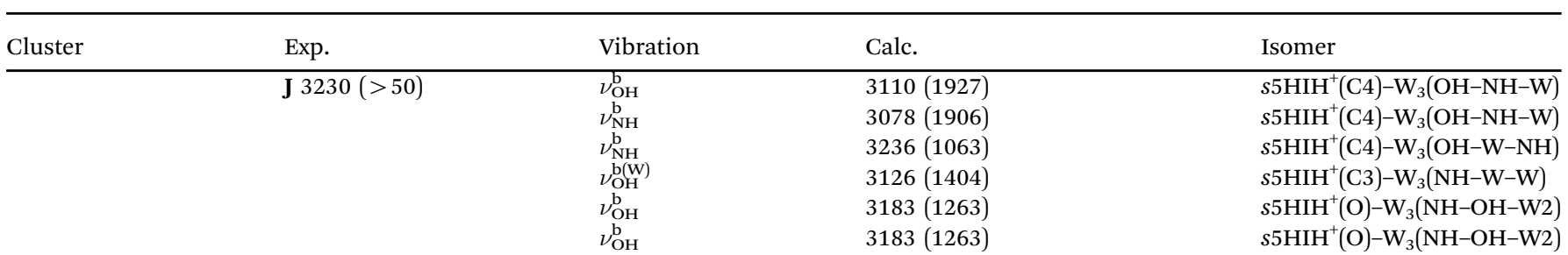

figures, we concentrate on $s 5 \mathrm{HIH}^{+}-\mathrm{W}_{n}$. Corresponding data for $a 5 \mathrm{HIH}^{+}-\mathrm{W}_{n}$ are available in the ESI. $\dagger$

Fig. 2 summarizes the calculated $s 5 \mathrm{HIH}^{+}-\mathrm{W}$ clusters relevant for the present study, along with their binding and relative energies $\left(D_{0}\right.$, $\left.E_{0}\right)$ and intermolecular $\mathrm{H}$-bond lengths $(R)$. Additional geometric and spectroscopic properties are listed in Table S1 (ESI $\dagger$ ). Further stable binding motifs of $s 5 \mathrm{HIH}^{+}-\mathrm{W}$ are shown in Fig. S2, and corresponding structures of $a 5 \mathrm{HIH}^{+}-\mathrm{W}$ are given in Fig. S3 (Table S1, ESI†).
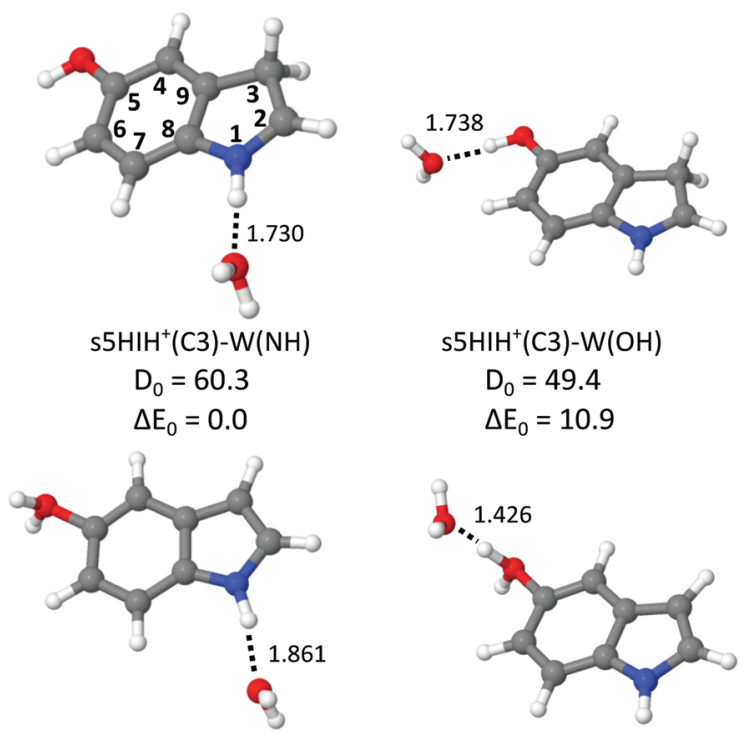

s5 $\mathrm{HIH}^{+}(\mathrm{O})-\mathrm{W}(\mathrm{NH})$

$D_{0}=39.5$

$\Delta \mathrm{E}_{0}=137.9$

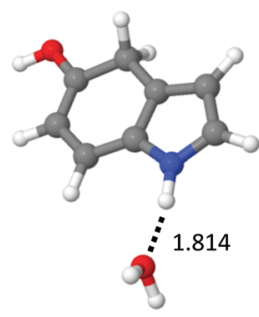

$\mathrm{s} 5 \mathrm{HIH}^{+}(\mathrm{C} 4)-\mathrm{W}(\mathrm{NH})$

$\mathrm{D}_{0}=48.7$

$\Delta \mathrm{E}_{0}=16.7$

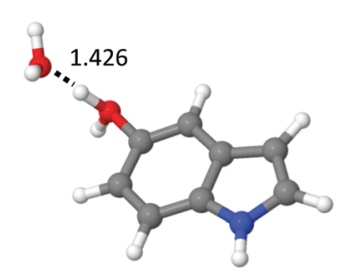

s5 $\mathrm{HIH}^{+}(\mathrm{O})-\mathrm{W}(\mathrm{OH})$

$D_{0}=99.3$

$\Delta \mathrm{E}_{0}=78.2$

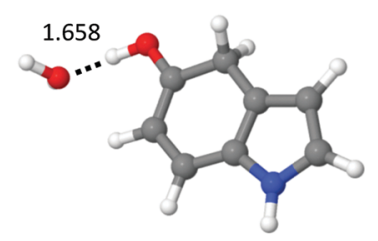

s5 $\mathrm{HIH}^{+}(\mathrm{C} 4)-\mathrm{W}(\mathrm{OH})$

$D_{0}=61.8$

$\Delta \mathrm{E}_{0}=3.6$

Fig. 2 Structures of selected $s 5 \mathrm{HIH}^{+}-\mathrm{W}$ clusters calculated at the B3LYP-D3/ aug-cc-pVTZ level (Table S1, ESI $\dagger$ ) along with binding energies and relative energies $\left(D_{0}\right.$ and $E_{0}$ in $\mathrm{kJ} \mathrm{mol}^{-1}$ ) and intermolecular bond lengths ( $R$ in $\AA$ ).
All $5 \mathrm{HIH}^{+}$protomers exhibit competing $\mathrm{H}$-bonding sites, and most important are the acidic functional $\mathrm{OH}_{(2)}$ and $\mathrm{NH}$ groups acting as proton donors in $\mathrm{OH} \cdots \mathrm{O}$ and $\mathrm{NH} \cdots \mathrm{O}$ H-bonds to W. As already observed for related heterocyclic arene cations, ${ }^{23,36,41,51-53} \pi$-stacking of $\mathrm{W}$ is rather unfavorable, e.g., $D_{0}=33.3 \mathrm{~kJ} \mathrm{~mol}^{-1}$ for $s 5 \mathrm{HIH}^{+}(\mathrm{C} 3)-\mathrm{W}(\pi)$, and thus not considered further. Only one isomer with $\mathrm{W}$ attached to the protonated $\mathrm{CH}_{2}$ group could be located, namely, $s 5 \mathrm{HIH}^{+}(\mathrm{C} 4)-\mathrm{W}(\mathrm{CH})$ with $D_{0}=28.6 \mathrm{~kJ} \mathrm{~mol}^{-1}$. Because of the low binding energy of the $\mathrm{CH}$... O H-bonds, this binding motif is also not considered further. Depending on the protonation site, the acidity of the $\mathrm{OH}$ and $\mathrm{NH}$ functional groups is changed, ${ }^{17}$ and the $\mathrm{H}$-bond strengths vary in the same way. For example, the $\mathrm{NH}$ group is the strongest proton donor in $s 5 \mathrm{HIH}^{+}(\mathrm{C} 3)-\mathrm{W}(\mathrm{NH})\left(\Delta E_{0}=0\right.$ and $D_{0}=60.3 \mathrm{~kJ} \mathrm{~mol}^{-1}, R=1.730 \AA$ for $\left.\mathrm{NH} \cdots \mathrm{O}\right)$, while the $\mathrm{OH}$ group is preferred in $s 5 \mathrm{HIH}^{+}(\mathrm{C} 4)-\mathrm{W}(\mathrm{OH})\left(\Delta E_{0}=3.6\right.$ and $D_{0}=$ $61.8 \mathrm{~kJ} \mathrm{~mol}^{-1}, R=1.658 \AA$ for $\left.\mathrm{OH} \cdots \mathrm{O}\right)$. The $\mathrm{OH} \cdots \mathrm{O}$ H-bond of the protonated $\mathrm{OH}_{2}$ oxonium group is outstandingly strong, with $D_{0}=99.3 \mathrm{~kJ} \mathrm{~mol}^{-1}$ and $R=1.426 \AA$ for $s 5 \mathrm{HIH}^{+}(\mathrm{O})-\mathrm{W}(\mathrm{OH})$. This strong $\mathrm{H}$-bond and the twofold degeneracy may thus again somewhat compensate for the large energy gap of $\Delta E_{0}=$ $78.2 \mathrm{~kJ} \mathrm{~mol}^{-1}$ between $s 5 \mathrm{HIH}^{+}(\mathrm{O})-\mathrm{W}(\mathrm{OH})$ and the $s 5 \mathrm{HIH}^{+}(\mathrm{C} 3)-$ $\mathrm{W}(\mathrm{NH})$ global minimum. The $\mathrm{NH}$ group of the oxonium protomer is a far less acidic than the $\mathrm{OH}_{2}$ group, with $D_{0}=39.5 \mathrm{~kJ} \mathrm{~mol}^{-1}$ and $R=1.861 \AA$ for the $\mathrm{NH} \cdots \mathrm{O} \mathrm{H}$-bond in $s 5 \mathrm{HIH}^{+}(\mathrm{O})-\mathrm{W}(\mathrm{NH})$. All considered $s 5 \mathrm{HIH}^{+}-\mathrm{W}$ isomers are readily distinguishable by their IR spectra in the investigated spectral range (Fig. 3 and Fig. S4, $\mathrm{ESI} \dagger)$. Our calculated binding energies of $s 5 \mathrm{HIH}^{+}(\mathrm{C} 3)-\mathrm{W}(\mathrm{NH})$ and $s 5 \mathrm{HIH}^{+}(\mathrm{C} 3)-\mathrm{W}(\mathrm{OH}), D_{0}=60.3$ and $49.4 \mathrm{~kJ} \mathrm{~mol}^{-1}$, are substantially but systematically smaller than the corresponding $\mathrm{H}$-bond energies reported earlier at the RI-MP2/aug-cc-pVDZ level, $D_{\mathrm{e}}=88.6$ and $76.8 \mathrm{~kJ} \mathrm{~mol}^{-1} .^{5}$ Similar to the MP2 results, ${ }^{5}$ the single-point energies computed at the CC2/aug-cc-pVDZ level yield the same energy hierarchy as predicted at the B3LYP-D3/ aug-cc-pVTZ level, but the spread of relative energies is somewhat larger (Table S1, ESI $\dagger$ ). In general, BSSE corrections of the computed binding energies evaluated at the B3LYP-D3/augcc-pVTZ level are small (on the order of $1 \%$ or less) because the aug-cc-pVTZ basis set is rather large (Table S1, ESI $\dagger$ ). Reference calculations at the PBE0-D3/aug-cc-pVTZ level yield energies, structural and spectroscopic properties comparable to those obtained at the B3LYP-D3/aug-cc-pVTZ level (Table S1, ESI $\dagger$ ). Indeed, the IR spectra computed at the B3LYP-D3/aug-cc-pVTZ level match somewhat better the experimental spectra (Fig. S5, ESI $\dagger$ ).

In Fig. 3 the IRPD spectrum of $5 \mathrm{HIH}^{+}-\mathrm{W}$ is compared to that of cationic $5 \mathrm{HI}^{+}-\mathrm{W}$ and to linear IR absorption spectra calculated for relevant $s 5 \mathrm{HIH}^{+}-\mathrm{W}$ isomers (Table 1). The vibrational assignment 


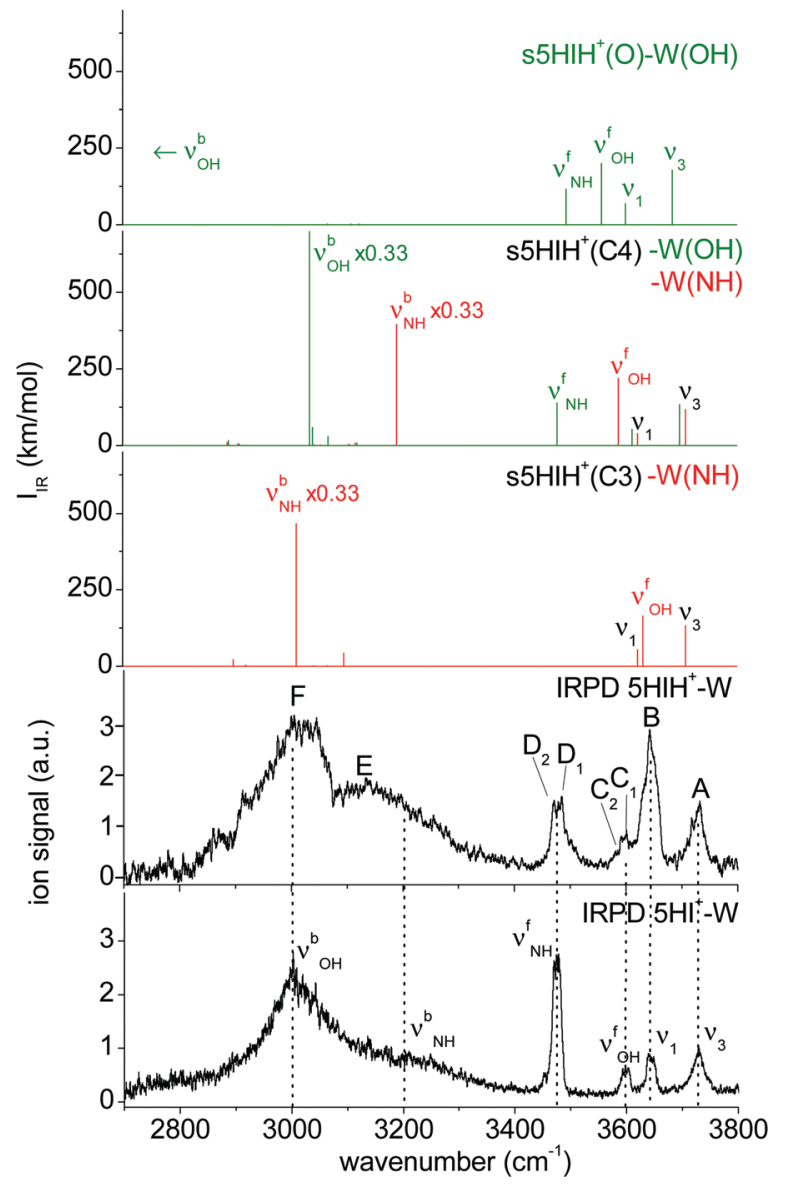

Fig. 3 Comparison of the IRPD spectrum of $5 \mathrm{HIH}^{+}-\mathrm{W}$ to linear IR spectra calculated for the most stable isomers at the B3LYP-D3/aug-cc-pVTZ level. For comparison, the IRPD spectrum of $5 \mathrm{HI}^{+}-\mathrm{W}$ is also shown. ${ }^{23}$

is facilitated by comparing the spectra of $5 \mathrm{HIH}^{+}-\mathrm{W}$ and $5 \mathrm{HI}^{+}-\mathrm{W}$. Bands A and B at 3732 and $3641 \mathrm{~cm}^{-1}$ are readily assigned to the antisymmetric and symmetric free $\mathrm{OH}$ stretching modes of $\mathrm{W}$ $\left(\nu_{3}\right.$ and $\left.\nu_{1}\right)$. Band A may also contain the red-shifted $\nu_{3}$ mode of $s 5 \mathrm{HIH}^{+}(\mathrm{O})-\mathrm{W}(\mathrm{OH})$ and $s 5 \mathrm{HIH}^{+}(\mathrm{C} 4)-\mathrm{W}(\mathrm{OH})$ predicted at 3685 and $3697 \mathrm{~cm}^{-1}$, respectively. The relative intensity of band $\mathrm{B}$ is substantially enhanced for $5 \mathrm{HIH}^{+}-\mathrm{W}$ as compared to $5 \mathrm{HI}^{+}-$ $\mathrm{W}$, while this is not the case for band A. Some contribution of the free phenolic $\mathrm{OH}$ stretching mode $\left(\nu_{\mathrm{OH}}^{\mathrm{f}}\right)$ of $s 5 \mathrm{HIH}^{+}(\mathrm{C} 3)-\mathrm{W}(\mathrm{NH})$ predicted at $3632 \mathrm{~cm}^{-1}$ rationalizes the higher intensity of band $\mathrm{B}$. Indeed, comparison of the IRPD spectra of $5 \mathrm{HIH}^{+}-\mathrm{L}$ with $\mathrm{L}=\mathrm{Ar}, \mathrm{N}_{2}$, and $\mathrm{W}$ further strengthens this assignment. ${ }^{17}$ The $\nu_{\mathrm{OH}}^{\mathrm{f}}$ band of $s 5 \mathrm{HIH}^{+}(\mathrm{C} 3)-\operatorname{Ar}(\pi)$ is observed at $3635 \mathrm{~cm}^{-1}$, that is only $6 \mathrm{~cm}^{-1}$ red-shifted from the maximum of peak B. By comparison to $5 \mathrm{HI}^{+}-\mathrm{W}$, bands $\mathrm{C}_{1} / \mathrm{C}_{2}$ are clearly assigned to phenolic $\nu_{\mathrm{OH}}^{\mathrm{f}}$ modes. We attribute $\mathrm{C}_{1}$ at $3600 \mathrm{~cm}^{-1}$ to $\nu_{\mathrm{OH}}^{\mathrm{f}}$ of $s 5 \mathrm{HIH}^{+}(\mathrm{C} 4)-\mathrm{W}(\mathrm{NH})$ predicted at $3588 \mathrm{~cm}^{-1}$, and $\mathrm{C}_{2}$ at $3591 \mathrm{~cm}^{-1}$ to $\nu_{\mathrm{OH}}^{\mathrm{f}}$ of $s 5 \mathrm{HIH}^{+}(\mathrm{O})-\mathrm{W}(\mathrm{OH})$ predicted at $3558 \mathrm{~cm}^{-1}$. Another indication for the production of $s 5 \mathrm{HIH}^{+}(\mathrm{O})-\mathrm{W}(\mathrm{OH})$ is the doublet $\mathrm{D}_{1} / \mathrm{D}_{2}$ at $3485 / 3470 \mathrm{~cm}^{-1}\left(\Delta \nu=15 \mathrm{~cm}^{-1}\right)$. By analogy to $5 \mathrm{HI}^{+}-\mathrm{W}$, it is assigned to the free $\mathrm{NH}$ stretching mode $\left(\nu_{\mathrm{NH}}^{\mathrm{f}}\right)$. Here, $\mathrm{D}_{1}$ is attributed to $s 5 \mathrm{HIH}^{+}(\mathrm{O})-\mathrm{W}(\mathrm{OH})$ and $\mathrm{D}_{2}$ to $s 5 \mathrm{HIH}^{+}(\mathrm{C} 4)-\mathrm{W}(\mathrm{OH})$ predicted at 3494 and $3478 \mathrm{~cm}^{-1}\left(\Delta \nu=16 \mathrm{~cm}^{-1}\right)$, respectively.
The broad band E centered at $3130 \mathrm{~cm}^{-1}$ is interpreted as $\mathrm{H}$-bonded $\mathrm{NH}$ stretch $\left(\nu_{\mathrm{NH}}^{\mathrm{b}}\right)$ of $s 5 \mathrm{HIH}^{+}(\mathrm{C} 4)-\mathrm{W}(\mathrm{NH})$ predicted at $3191 \mathrm{~cm}^{-1}$. Band $\mathrm{E}$ is somewhat red-shifted compared to $\nu_{\mathrm{NH}}^{\mathrm{b}}$ in the IRPD spectrum of cationic $5 \mathrm{HI}^{+}-\mathrm{W}$, indicating a destabilization of the $\mathrm{NH}$ bond induced by C4-protonation. The broad transition $\mathrm{F}$ at $3015 \mathrm{~cm}^{-1}$ contains both $\nu_{\mathrm{OH}}^{\mathrm{b}}$ of $s 5 \mathrm{HIH}^{+}(\mathrm{C} 4)-\mathrm{W}(\mathrm{OH})$ and $\nu_{\mathrm{NH}}^{\mathrm{b}}$ of $s 5 \mathrm{HIH}^{+}(\mathrm{C} 3)-\mathrm{W}(\mathrm{NH})$ predicted at 3035 and $3011 \mathrm{~cm}^{-1}$. The IRPD spectrum shows no clear signature of the $s 5 \mathrm{HIH}^{+}(\mathrm{C} 3)-\mathrm{W}(\mathrm{OH})$ isomer (Fig. S4, ESI $\dagger$ ). This finding is somewhat surprising because this isomer is predicted to be slightly more stable than $s 5 \mathrm{HIH}^{+}(\mathrm{C} 4)-\mathrm{W}(\mathrm{NH})\left(\Delta E_{0}=10.9\right.$ and $D_{0}=49.4 \mathrm{~kJ} \mathrm{~mol}^{-1} v s . \Delta E_{0}=$ 16.7 and $\left.D_{0}=48.7 \mathrm{~kJ} \mathrm{~mol}^{-1}\right)$. We also rule out the presence of the $s 5 \mathrm{HIH}^{+}(\mathrm{O})-\mathrm{W}(\mathrm{NH})$ isomer, mostly on the basis of stability and spectroscopy (Fig. S4, ESI $\dagger$ ).

In conclusion, we assign the measured IRPD spectrum of $5 \mathrm{HIH}^{+}-\mathrm{W}$ to C3-protonated $s 5 \mathrm{HIH}^{+}(\mathrm{C} 3)-\mathrm{W}(\mathrm{NH})$ with $\mathrm{NH}$-bonded $\mathrm{W}$, C4-protonated $s 5 \mathrm{HIH}^{+}(\mathrm{C} 4)-\mathrm{W}(\mathrm{OH})$ and $s 5 \mathrm{HIH}^{+}(\mathrm{C} 4)-\mathrm{W}(\mathrm{NH})$ with $\mathrm{OH}^{-}$and $\mathrm{NH}$-bonded $\mathrm{W}$, and the $\mathrm{OH}-$ bonded $s 5 \mathrm{HIH}^{+}(\mathrm{O})-$ $\mathrm{W}(\mathrm{OH})$ oxonium ion. This interpretation is strengthened by a comparison of the IRPD spectrum to exemplary anharmonic spectra computed for the monohydrates (Fig. S6 and Table S1, ESI $\dagger$ ). Obviously, within the harmonic approximation, the redshifts of the $\mathrm{H}$-bond donor stretching vibrations $\left(\nu_{\mathrm{OH}}^{\mathrm{b}}\right.$ and $\left.\nu_{\mathrm{NH}}^{\mathrm{b}}\right)$ are underestimated by $60-110 \mathrm{~cm}^{-1}$, but both the anharmonic and scaled harmonic spectra yield the same assignment of the experimental transitions. At the current experimental resolution, we cannot discriminate syn and anti rotamers but assume that both are present in significant abundance for the assigned isomers. The estimation of population ratios for the three protomers $(\mathrm{C} 3, \mathrm{C} 4, \mathrm{O})$ based on the comparison of measured and computed band intensities is not straightforward due to overlapping transitions. Furthermore, the binding energies of the $5 \mathrm{HIH}^{+}-\mathrm{W}$ clusters are higher than the IR photon energies in the $\mathrm{XH}$ stretch range, such that absorption of a single photon will not lead to fragmentation from cold clusters. Hence, multiple-photon effects or ions with high internal energy must be considered. Moreover, due to the very different binding energies of the individual $5 \mathrm{HIH}^{+}-\mathrm{W}$ clusters, the photodissociation cross sections may be different, too. Still, assuming similar fragmentation cross sections for the assigned isomers, a rough estimate of populations is possible. In contrast to the predictions for $55 \mathrm{HIH}^{+}(\mathrm{O})-\mathrm{W}(\mathrm{OH})$, band $\mathrm{C}\left(\mathrm{C}_{1}+\mathrm{C}_{2}, \nu_{\mathrm{OH}}^{\mathrm{f}}\right)$ is significantly less intense than $\mathrm{D}\left(\mathrm{D}_{1}+\mathrm{D}_{2}, \nu_{\mathrm{NH}}^{\mathrm{f}}\right)$. This result suggests that we probe only a few oxonium ions $(\sim 10 \%)$, while the main contribution to band D arises from $s 5 \mathrm{HIH}^{+}(\mathrm{C} 4)-\mathrm{W}(\mathrm{OH})$. The comparison of bands $\mathrm{C}$ and $\mathrm{D}$ also indicates that significantly fewer $s 5 \mathrm{HIH}^{+}(\mathrm{C} 4)-\mathrm{W}(\mathrm{NH})$ than $s 5 \mathrm{HIH}^{+}(\mathrm{C} 4)-\mathrm{W}(\mathrm{OH})$ isomers are probed. Band B is roughly twice as intense as band A, while $\nu_{1}$ is predicted to be half as intense as $\nu_{3}$ in any of the calculated IR spectra. Thus, we conclude that most signals of band B stem from $\nu_{\mathrm{OH}}^{\mathrm{f}}$ of $s 5 \mathrm{HIH}^{+}(\mathrm{C} 3)-$ $\mathrm{W}(\mathrm{NH})$. Hence, we suggest that the major contribution (roughly $70 \%)$ to the IRPD spectrum arises from the most stable $s 5 \mathrm{HIH}^{+}(\mathrm{C} 3)-$ $\mathrm{W}(\mathrm{NH})$ and $s 5 \mathrm{HIH}^{+}(\mathrm{C} 4)-\mathrm{W}(\mathrm{OH})$ isomers.

\section{$3.3 \quad 5 \mathrm{HIH}^{+}-\mathrm{W}-\mathrm{Ar} / \mathbf{N}_{2}$}

Tagging with $\mathrm{Ar}$ or $\mathrm{N}_{2}$ reduces the peak widths in the IRPD spectra of $5 \mathrm{HIH}^{+}-\mathrm{W}$ because the binding energy of the least 
bonded ligand limits the internal temperature of the cluster. Fig. S7 and S8 (ESI $\dagger$ ) compare the IRPD spectra of $5 \mathrm{HIH}^{+}-\mathrm{W}-\mathrm{Ar}$ and $5 \mathrm{HIH}^{+}-\mathrm{W}-\mathrm{N}_{2}$ to the IR spectra calculated for relevant tagged isomers. The IRPD spectra of $5 \mathrm{HIH}^{+}-\mathrm{W}-\mathrm{Ar} / \mathrm{N}_{2}$ do not add any new information about the monohydrated clusters but confirm the assignment of $s 5 \mathrm{HIH}^{+}(\mathrm{C} 3)-\mathrm{W}(\mathrm{NH}), s 5 \mathrm{HIH}^{+}(\mathrm{C} 4)-\mathrm{W}(\mathrm{OH})$, $s 5 \mathrm{HIH}^{+}(\mathrm{C} 4)-\mathrm{W}(\mathrm{NH})$ and $s 5 \mathrm{HIH}^{+}(\mathrm{O})-\mathrm{W}(\mathrm{OH})$ being the predominant monohydrates in the molecular beam. The Ar tag is mainly attached to the $\mathrm{W}$ moiety or $\pi$-stacked. The $\mathrm{N}_{2}$ ligand is $\mathrm{H}$-bonded to either $\mathrm{W}$ or to the remaining functional group not occupied by $\mathrm{W}$.
Selected structures of $s 5 \mathrm{HIH}^{+}-\mathrm{W}-\mathrm{Ar}$ and $s 5 \mathrm{HIH}^{+}-\mathrm{W}-\mathrm{N}_{2}$ are depicted in Fig. S9 and S10 (ESI $\dagger$ ), respectively, and Table S1 (ESI $\dagger$ ) contains structural and spectroscopic information for all calculated $5 \mathrm{HIH}^{+}-\mathrm{W}-\mathrm{Ar} / \mathrm{N}_{2}$ isomers. For a detailed discussion of the $5 \mathrm{HIH}^{+}-\mathrm{W}-\mathrm{L}$ spectra, the interested reader is referred to the ESI. $\dagger$

\section{$3.45 \mathrm{HIH}^{+}-\mathrm{W}_{2}$}

Fig. 4 shows the structures of selected $s 5 \mathrm{HIH}^{+}-\mathrm{W}_{2}$ clusters along with binding energies and $\mathrm{H}$-bond lengths. Additional

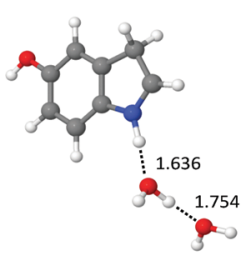

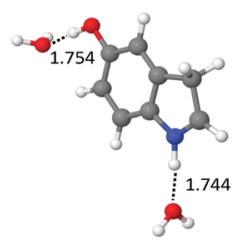

$\mathrm{s} 5 \mathrm{HIH}^{+}(\mathrm{C} 3)-\mathrm{W}_{2}(\mathrm{NH}-\mathrm{OH})$

$D_{0}=106.4$

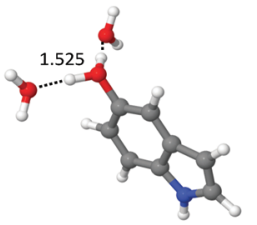

$\mathrm{S} 5 \mathrm{HIH}^{+}(\mathrm{O})-\mathrm{W}_{2}(\mathrm{OH}-\mathrm{OH})$

$D_{0}=176.7$

$\mathrm{D}_{0}=104.5$

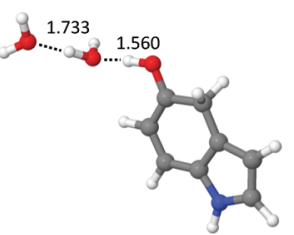

s5 $\mathrm{HIH}^{+}(\mathrm{C} 4)-\mathrm{W}_{2}(\mathrm{OH}-\mathrm{W})$

$\mathrm{D}_{0}=106.1$

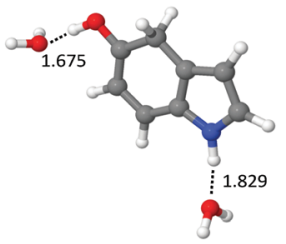

$\mathrm{S} 5 \mathrm{HIH}^{+}(\mathrm{C} 4)-\mathrm{W}_{2}(\mathrm{NH}-\mathrm{OH})$

$D_{0}=106.6$
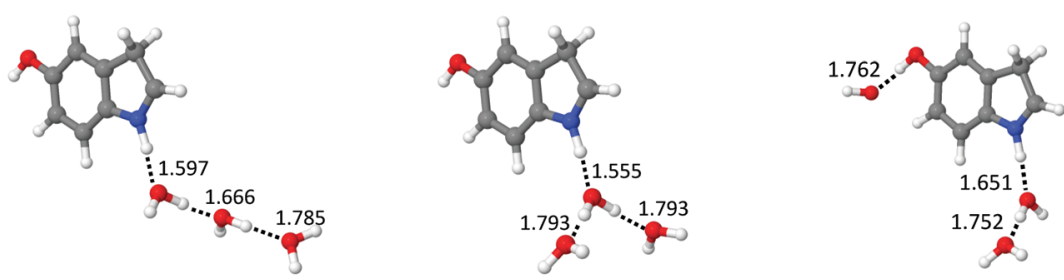

$\mathrm{s} 5 \mathrm{HIH}^{+}(\mathrm{C} 3)-\mathrm{W}_{3}(\mathrm{NH}-\mathrm{W}-\mathrm{W})$

$\mathrm{s} 5 \mathrm{HIH}^{+}(\mathrm{C} 3)-\mathrm{W}_{3}(\mathrm{~W}-\mathrm{NH}-\mathrm{W})$

$\mathrm{s} 5 \mathrm{HIH}^{+}(\mathrm{C} 3)-\mathrm{W}_{3}(\mathrm{OH}-\mathrm{NH}-\mathrm{W})$

$D_{0}=140.8$

$D_{0}=141.9$

$\mathrm{D}_{0}=148.4$
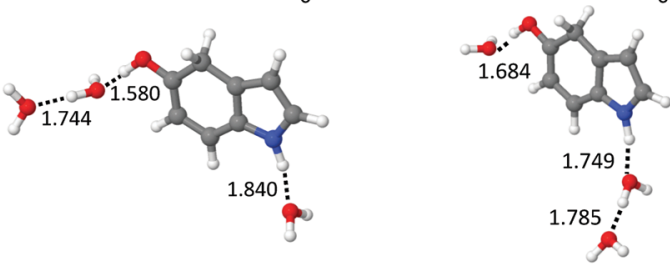

s5HIH ${ }^{+}(\mathrm{C} 4)-\mathrm{W}_{3}(\mathrm{OH}-\mathrm{W}-\mathrm{NH}) \quad \mathrm{s} 5 \mathrm{HIH}^{+}(\mathrm{C} 4)-\mathrm{W}_{3}(\mathrm{OH}-\mathrm{NH}-\mathrm{W})$

$D_{0}=148.9$

$D_{0}=143.4$

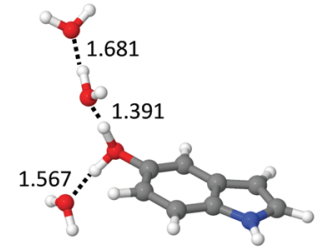

$\mathrm{s} 5 \mathrm{HIH}^{+}(\mathrm{O})-\mathrm{W}_{3}(\mathrm{OH}-\mathrm{OH}-\mathrm{W} 1)$

$\mathrm{D}_{0}=229.2$
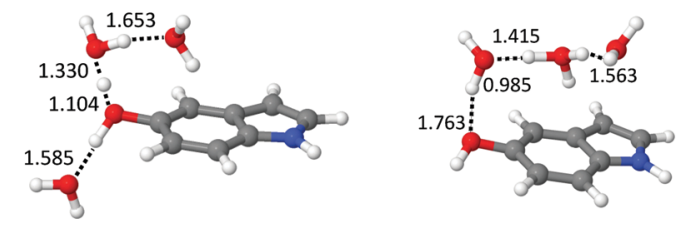

$\mathrm{s} 5 \mathrm{HIH}^{+}(\mathrm{O})-\mathrm{W}_{3}(\mathrm{OH}-\mathrm{OH}-\mathrm{W} 2)$

$D_{0}=231.5$

$55 \mathrm{HIH}^{+}(\mathrm{O})-\mathrm{W}_{3}(\mathrm{OH}-\mathrm{W}-\mathrm{W} 2)$

$\mathrm{D}_{0}=231.8$

Fig. 4 Structures of selected $s 5 \mathrm{HIH}^{+}-\mathrm{W}_{2 / 3}$ clusters calculated at the B3LYP-D3/aug-cc-pVTZ level (Table S1, ESI $\dagger$ ) along with binding energies $\left(D_{0}\right.$ in $\left.\mathrm{kJ} \mathrm{mol}^{-1}\right)$ and intermolecular distances $(R$ in $\AA$ ). 
stable $s 5 \mathrm{HIH}^{+}-\mathrm{W}_{2}$ isomers are shown in Fig. S11 (ESI $\dagger$ ). Corresponding $a 5 \mathrm{HIH}^{+}-\mathrm{W}_{2}$ structures are depicted in Fig. S12 (ESI $\dagger$ ). Selected structural and spectroscopic properties of all calculated $s / a 5 \mathrm{HIH}^{+}-\mathrm{W}_{2}$ isomers are listed in Table $\mathrm{S} 1$ (ESI $\dagger$ ).

For $5 \mathrm{HIH}^{+}(\mathrm{C} 3 / \mathrm{C} 4)-\mathrm{W}_{2}$, we consider three binding motifs. $\mathrm{H}$-bonding of two individual $\mathrm{W}$ ligands to both functional groups yields the most stable $s 5 \mathrm{HIH}^{+}(\mathrm{C} 3 / \mathrm{C} 4)-\mathrm{W}_{2}(\mathrm{NH}-\mathrm{OH})$ with $D_{0}=106.4 / 106.6 \mathrm{~kJ} \mathrm{~mol}^{-1}$. BSSE corrections are again on the order of $1 \%$ of the computed binding energies (Table S1, ESI $\dagger$ ). Noncooperative three-body effects weaken the individual $\mathrm{H}$ bonds compared to the monohydrates, as revealed by comparison of binding energies and $\mathrm{H}$-bond lengths. For example, corresponding $\mathrm{H}$-bonds elongate from $R=1.730$ and $1.738 \AA$ in $s 5 \mathrm{HIH}^{+}(\mathrm{C} 3)-\mathrm{W}(\mathrm{NH})$ and $s 5 \mathrm{HIH}^{+}(\mathrm{C} 3)-\mathrm{W}(\mathrm{OH})$ to $R=1.744$ and $1.754 \AA$ in $s 5 \mathrm{HIH}^{+}(\mathrm{C} 3)-\mathrm{W}_{2}(\mathrm{NH}-\mathrm{OH})$. The same trend holds for $s 5 \mathrm{HIH}^{+}(\mathrm{C} 4)-\mathrm{W}_{2}(\mathrm{NH}-\mathrm{OH})$ with $R=1.814$ and $1.658 \AA$ compared to $R=1.829$ and $1.675 \AA$ A. This weakening of the H-bonds directly translates into reduced complexation-induced redshifts of the corresponding $\nu_{\mathrm{NH}}^{\mathrm{b}}$ and $\nu_{\mathrm{OH}}^{\mathrm{b}}$ modes (Table S1, ESI $\dagger)$. For example, $\nu_{\mathrm{NH}}^{\mathrm{b}}$ of $s 5 \mathrm{HIH}^{+}(\mathrm{C} 3)-\mathrm{W}(\mathrm{NH})$ is predicted at $3011 \mathrm{~cm}^{-1}$ and that of $s 5 \mathrm{HIH}^{+}(\mathrm{C} 3)-\mathrm{W}_{2}(\mathrm{NH}-\mathrm{OH})$ at $3041 \mathrm{~cm}^{-1}$. For the C3-protonated ion, formation of a $\mathrm{H}$-bonded water network (i.e., attachment of a $\mathrm{H}$-bonded $\mathrm{W}_{2}$ ) at the $\mathrm{NH}$ group is more favorable than at the $\mathrm{OH}$ group, with $D_{0}=104.5$ and $86.8 \mathrm{~kJ} \mathrm{~mol}^{-1}$ for $s 5 \mathrm{HIH}^{+}(\mathrm{C} 3)-\mathrm{W}_{2}(\mathrm{NH}-\mathrm{W})$ and $s 5 \mathrm{HIH}^{+}(\mathrm{C} 3)-$ $\mathrm{W}_{2}(\mathrm{OH}-\mathrm{W})$, respectively. Due to cooperativity, the initial H-bond is shortened from $R=1.730 \AA$ in $s 5 \mathrm{HIH}^{+}(\mathrm{C} 3)-\mathrm{W}(\mathrm{NH})$ to $1.636 \AA$ in $s 5 \mathrm{HIH}^{+}(\mathrm{C} 3)-\mathrm{W}_{2}(\mathrm{NH}-\mathrm{W})$. In line with the altered acidity of the functional groups for the C4-protonated ion, ${ }^{17}$ $s 5 \mathrm{HIH}^{+}(\mathrm{C} 4)-\mathrm{W}_{2}(\mathrm{OH}-\mathrm{W})$ is more stable than $s 5 \mathrm{HIH}^{+}(\mathrm{C} 4)-$ $\mathrm{W}_{2}(\mathrm{NH}-\mathrm{W})$, with $D_{0}=106.1$ and $87.6 \mathrm{~kJ} \mathrm{~mol}^{-1}$, respectively. Again, network formation strengthens the first $\mathrm{H}$-bond with $R=1.658 \AA$ in $s 5 \mathrm{HIH}^{+}(\mathrm{C} 4)-\mathrm{W}(\mathrm{OH})$ vs. $1.560 \AA$ in $s 5 \mathrm{HIH}^{+}(\mathrm{C} 4)-$ $\mathrm{W}_{2}(\mathrm{OH}-\mathrm{W})$. Formation of water networks yields characteristic spectroscopic features, most prominently, $\nu_{\mathrm{OH}}^{\mathrm{f}(\mathrm{W})}$ and $\nu_{\mathrm{OH}}^{\mathrm{b}(\mathrm{W})}$ of the solvated water in the $\mathrm{W}_{2}$ unit, predicted at 3690 and $3307 \mathrm{~cm}^{-1}$ for $s 5 \mathrm{HIH}^{+}(\mathrm{C} 3)-\mathrm{W}_{2}(\mathrm{NH}-\mathrm{W})$. The corresponding $\nu_{3}$ and $\nu_{1}$ of the terminal free water are blue-shifted from 3708 and $3622 \mathrm{~cm}^{-1}$ in $s 5 \mathrm{HIH}^{+}(\mathrm{C} 3)-\mathrm{W}(\mathrm{NH})$ to 3717 and $3628 \mathrm{~cm}^{-1}$ in $s 5 \mathrm{HIH}^{+}(\mathrm{C} 3)_{-}$ $\mathrm{W}_{2}(\mathrm{NH}-\mathrm{W})$. The impact on the respective functional group by solvation with $\mathrm{W}_{2}$ is largely enhanced. For example, $\nu_{\mathrm{OH}}^{\mathrm{b}}$ of $s 5 \mathrm{HIH}^{+}(\mathrm{C} 4)-\mathrm{W}_{2}(\mathrm{OH})$ is predicted at $3035 \mathrm{~cm}^{-1}$ and shifts down to $2710 \mathrm{~cm}^{-1}$ for $s 5 \mathrm{HIH}^{+}(\mathrm{C} 4)-\mathrm{W}_{2}(\mathrm{OH}-\mathrm{W})$.

The largest binding energy of $D_{0}=176.7 \mathrm{~kJ} \mathrm{~mol}^{-1}$ is calculated for $s 5 \mathrm{HIH}^{+}(\mathrm{O})-\mathrm{W}_{2}(\mathrm{OH}-\mathrm{OH})$, i.e. the oxonium ion monohydrated at both $\mathrm{OH}$ groups. Yet, due to noncooperativity, this value is significantly lower than twice the binding energy of $s 5 \mathrm{HIH}^{+}(\mathrm{O})-\mathrm{W}(\mathrm{OH}), D_{0}=99.3 \mathrm{~kJ} \mathrm{~mol}^{-1}$. Formation of a water network at the $\mathrm{OH}_{2}$ group yields $s 5 \mathrm{HIH}^{+}(\mathrm{O})-\mathrm{W}_{2}(\mathrm{OH}-\mathrm{W} 1)$ and $s 5 \mathrm{HIH}^{+}(\mathrm{O})-\mathrm{W}_{2}(\mathrm{OH}-\mathrm{W} 2)$ with $D_{0}=167.3$ and $169.7 \mathrm{~kJ} \mathrm{~mol}^{-1}$ (Fig. S11, ESI $\dagger$ ). The $\mathrm{NH}$ group of the oxonium ion is far less attractive, leading to $s 5 \mathrm{HIH}^{+}(\mathrm{O})-\mathrm{W}_{2}(\mathrm{NH}-\mathrm{OH})$ and $s 5 \mathrm{HIH}^{+}(\mathrm{O})-$ $\mathrm{W}_{2}(\mathrm{NH}-\mathrm{W})$ with only $D_{0}=135.5$ and $73.4 \mathrm{~kJ} \mathrm{~mol}^{-1}$. Again, BSSE corrections are on the order of only $1 \%$ of the computed binding energies (Table $\mathrm{S} 1, \mathrm{ESI} \dagger)$. In $s 5 \mathrm{HIH}^{+}(\mathrm{O})-\mathrm{W}_{2}(\mathrm{OH}-\mathrm{W} 1)$, the water chain points away from the phenol ring. Proton transfer to the $\mathrm{W}_{2}$ chain is indicated, because the $\mathrm{OH}$ bond of $s 5 \mathrm{HIH}^{+}(\mathrm{O})$ is already longer $\left(r_{\mathrm{OH}}=1.262 \AA\right)$ than the $\mathrm{OH} \cdots \mathrm{W}$ bond $(R=1.147 \AA)$. Thus, the ion may be better described by $s 5 \mathrm{HI}-\mathrm{H}_{5} \mathrm{O}_{2}{ }^{+}$. Yet, for consistency, we keep the introduced notation for the structures. On the other hand, in $s 5 \mathrm{HIH}^{+}(\mathrm{O})-\mathrm{W}_{2}(\mathrm{OH}-\mathrm{W} 2)$ the water chain is bent toward the aromatic ring facilitating an additional $\mathrm{OH} \cdots \pi$ interaction with the aromatic $\pi$-electron cloud. In this structure, proton transfer is more pronounced, with $r_{\mathrm{OH}}=1.434$ and $R=1.056 \AA$.

The assignment of the IRPD spectrum of $5 \mathrm{HIH}^{+}-\mathrm{W}_{2}$ (Table 1 ) is based on the comparison to the corresponding calculated spectra (Fig. 5 and Fig. S13, ESI $\dagger$ ). Exemplary anharmonic spectra depicted in Fig. S14 (ESI $\dagger$ ) are in line with the following assignments based on the harmonic spectra. Bands A and B at 3725 and $3638 \mathrm{~cm}^{-1}$ are readily assigned to $\nu_{3}$ and $\nu_{1}$ and are well reproduced by essentially all considered isomers. Band $\mathrm{G}$ at $3692 \mathrm{~cm}^{-1}$ is characteristic of an H-bonded $\mathrm{W}_{2}$ network and appears at 3690 and $3676 \mathrm{~cm}^{-1}$ in the calculated spectra of $s 5 \mathrm{HIH}^{+}(\mathrm{C} 3)-\mathrm{W}_{2}(\mathrm{NH}-\mathrm{W})$ and $s 5 \mathrm{HIH}^{+}(\mathrm{C} 4)-\mathrm{W}_{2}(\mathrm{OH}-\mathrm{W})$, respectively. In line with the assignments above, $\nu_{\mathrm{OH}}^{\mathrm{f}}$ of $s 5 \mathrm{HIH}^{+}(\mathrm{C} 3)-\mathrm{W}_{2}(\mathrm{NH}-\mathrm{W})$ predicted at $3635 \mathrm{~cm}^{-1}$ contributes to band $\mathrm{B}$, which is again significantly more intense than band A. The $\nu_{\mathrm{NH}}^{\mathrm{f}}$ mode characteristic of $s 5 \mathrm{HIH}^{+}(\mathrm{C} 4)-\mathrm{W}_{2}(\mathrm{OH}-\mathrm{W})$ at $3481 \mathrm{~cm}^{-1}$ is however not observed. Hence, we assign only $s 5 \mathrm{HIH}^{+}(\mathrm{C} 3)-\mathrm{W}_{2}(\mathrm{NH}-\mathrm{W})$. Consequently, band $\mathrm{H}$ centered at $3348 \mathrm{~cm}^{-1}$ is attributed to a superposition of $\nu_{\mathrm{OH}}^{\mathrm{b}}$ of $s 5 \mathrm{HIH}^{+}(\mathrm{C} 3)-\mathrm{W}_{2}(\mathrm{NH}-\mathrm{OH})$ predicted at

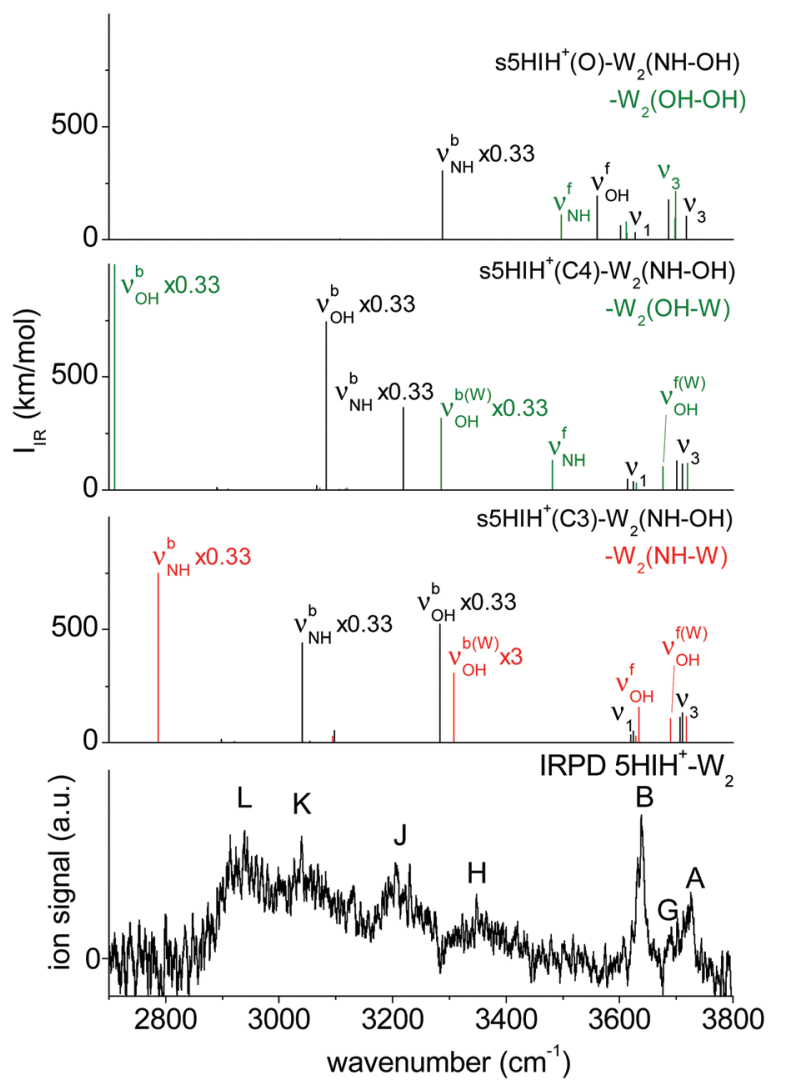

Fig. 5 Comparison of the IRPD spectrum of $5 \mathrm{HIH}^{+}-\mathrm{W}_{2}$ to calculated IR spectra of the relevant isomers at the B3LYP-D3/aug-cc-pVTZ level. 
$3283 \mathrm{~cm}^{-1}$ and $\nu_{\mathrm{OH}}^{\mathrm{b}}$ of the $\mathrm{W}_{2}$ unit in $s 5 \mathrm{HIH}^{+}(\mathrm{C} 3)-\mathrm{W}_{2}(\mathrm{NH}-\mathrm{W})$, which is predicted at $3308 \mathrm{~cm}^{-1}\left(\nu_{\mathrm{OH}}^{\mathrm{b}(\mathrm{W})}\right)$. Band $\mathrm{J}$ at $3205 \mathrm{~cm}^{-1}$ arises from $\nu_{\mathrm{NH}}^{\mathrm{b}(\mathrm{W})}$ of $s 5 \mathrm{HIH}^{+}(\mathrm{C} 4)-\mathrm{W}_{2}(\mathrm{NH}-\mathrm{OH})$ predicted at $3218 \mathrm{~cm}^{-1}$. Its $\nu_{\mathrm{OH}}^{\mathrm{b}}$ mode at $3083 \mathrm{~cm}^{-1}$ and $\nu_{\mathrm{NH}}^{\mathrm{b}}$ of $s 5 \mathrm{HIH}^{+}(\mathrm{C} 3)_{-}$ $\mathrm{W}_{2}(\mathrm{NH}-\mathrm{OH})$ predicted at $3041 \mathrm{~cm}^{-1}$ account for band $\mathrm{K}$ observed at $3040 \mathrm{~cm}^{-1}$. Finally, band $\mathrm{L}$ at $2940 \mathrm{~cm}^{-1}$ may be assigned to $\nu_{\mathrm{NH}}^{\mathrm{b}}$ of $s 5 \mathrm{HIH}^{+}(\mathrm{C} 3)-\mathrm{W}_{2}(\mathrm{NH}-\mathrm{W})$, which is predicted to be rather low $\left(2787 \mathrm{~cm}^{-1}\right)$. However, below $2800 \mathrm{~cm}^{-1}$, the laser power is very low such that this mode may also not be detected. We cannot safely assign any $5 \mathrm{HIH}^{+}(\mathrm{O})-\mathrm{W}_{2}$ oxonium isomer because there is no strong signal in the IRPD spectrum around $3500 \mathrm{~cm}^{-1}$. In this range, the $\nu_{\mathrm{NH}}^{\mathrm{f}}$ and $\nu_{\mathrm{OH}}^{\mathrm{f}}$ modes of $s 5 \mathrm{HIH}^{+}(\mathrm{O})-\mathrm{W}_{2}(\mathrm{OH}-\mathrm{OH})$ and $s 5 \mathrm{HIH}^{+}(\mathrm{O})-\mathrm{W}_{2}(\mathrm{NH}-\mathrm{OH})$ are predicted $\left(3498\right.$ and $3560 \mathrm{~cm}^{-1}$, Fig. 5). Furthermore, the $\nu_{\mathrm{NH}}^{\mathrm{f}}$ modes of the two proton-transferred structures $s 5 \mathrm{HIH}^{+}(\mathrm{O})-\mathrm{W}_{2}(\mathrm{OH}-\mathrm{W} 1)$ and $s 5 \mathrm{HIH}^{+}(\mathrm{O})-\mathrm{W}_{2}(\mathrm{OH}-\mathrm{W} 2)$ and their intense $\nu_{\mathrm{OH}}^{\mathrm{b}}$ modes of the $\mathrm{H}$-bonded $\mathrm{W}_{2}$ are expected around $3500 \mathrm{~cm}^{-1}$ (Fig. S13, ESI $\dagger$ ). For the $5 \mathrm{HIH}^{+}-\mathrm{W}$ cluster, the population of the OH-bound oxonium isomer $s 5 \mathrm{HIH}^{+}(\mathrm{O})-\mathrm{W}(\mathrm{OH})$ was most likely enhanced by its high binding energy of $D_{0}=99.3 \mathrm{~kJ} \mathrm{~mol}^{-1}$ and the twofold degeneracy. However, degeneracy effects no longer promote the most stable $s 5 \mathrm{HIH}^{+}(\mathrm{O})-\mathrm{W}_{2}(\mathrm{OH}-\mathrm{OH})$ cluster or the formation of $\mathrm{W}_{2}$ chains in $s 5 \mathrm{HIH}^{+}(\mathrm{O})-\mathrm{W}_{2}(\mathrm{OH}-\mathrm{W} 1 / \mathrm{W} 2)$. Thus, our spectra do not indicate proton transfer for any of the $5 \mathrm{HIH}^{+}-\mathrm{W}_{n}$ clusters at $n=2$.

\section{$3.5 \quad 5 \mathrm{HIH}^{+}-\mathrm{W}_{3}$}

In $s / a 5 \mathrm{HIH}^{+}-\mathrm{W}_{3}$, interior ion solvation competes with water network formation. $\mathrm{W}_{3}$ chains at either one of the functional groups (NH-W-W and $\mathrm{OH}-\mathrm{W}-\mathrm{W})$ are comparably strong as bifurcated $\mathrm{W}_{3} \mathrm{H}$-bonds ( $\mathrm{W}-\mathrm{NH}-\mathrm{W}$ and $\mathrm{W}-\mathrm{OH}-\mathrm{W}$ ). Selected structures of $s 5 \mathrm{HIH}^{+}-\mathrm{W}_{3}$ are shown in Fig. 4. Additional $s 5 \mathrm{HIH}^{+}-\mathrm{W}_{3}$ and selected $a 5 \mathrm{HIH}^{+}-\mathrm{W}_{3}$ isomers are depicted in Fig. S15 and S16 (ESI $\dagger$ ). Corresponding structural and spectroscopic data are listed in Table S1 (ESI $\dagger$ ). Again, we observe a strong modulation in the acidity of the functional groups depending on the protonation site. As the $\mathrm{NH}$ group is more acidic in $s 5 \mathrm{HIH}^{+}(\mathrm{C} 3)$, formation of $\mathrm{W}_{3}$ networks at the $\mathrm{NH}$ site $\left(D_{0} \approx 141 \mathrm{~kJ} \mathrm{~mol}^{-1}\right)$ is favored over the $\mathrm{OH}$ site $\left(D_{0} \approx 119 \mathrm{~kJ} \mathrm{~mol}^{-1}\right)$. The bifurcated $\mathrm{W}-\mathrm{NH}-\mathrm{W}$ H-bond $\left(D_{0}=141.9 \mathrm{~kJ} \mathrm{~mol}^{-1}\right)$ is slightly favored over the linear $\mathrm{NH}-\mathrm{W}-\mathrm{W}$ chain $\left(D_{0}=140.8 \mathrm{~kJ} \mathrm{~mol}^{-1}\right)$. However, interior ion solvation with one water molecule attached to the $\mathrm{OH}$ group and two to the $\mathrm{NH}$ group yields the most stable $s 5 \mathrm{HIH}^{+}(\mathrm{C} 3)-\mathrm{W}_{3}(\mathrm{OH}-\mathrm{NH}-\mathrm{W})$ isomer with $D_{0}=148.4 \mathrm{~kJ} \mathrm{~mol}^{-1}$. In contrast, $\mathrm{W}_{3}$ networks at the $\mathrm{OH}$ site are preferred for $s 5 \mathrm{HIH}^{+}(\mathrm{C} 4)$ with $D_{0} \approx 142-145 \mathrm{~kJ} \mathrm{~mol}^{-1}$ (Table S1, ESI $\dagger$ ). Solvation of both functional groups yields $s 5 \mathrm{HIH}^{+}(\mathrm{C} 4)-\mathrm{W}_{3}(\mathrm{OH}-\mathrm{W}-\mathrm{NH})$ and $s 5 \mathrm{HIH}^{+}(\mathrm{C} 4)-\mathrm{W}_{3}(\mathrm{OH}-\mathrm{NH}-\mathrm{W})$ with $D_{0}=148.9$ and $143.4 \mathrm{~kJ} \mathrm{~mol}^{-1}$ (Fig. 4). Noncooperative effects destabilize the individual $\mathrm{W}_{2}$ chains. For example, comparing $s 5 \mathrm{HIH}^{+}(\mathrm{C} 4)-\mathrm{W}_{2}(\mathrm{OH}-\mathrm{W})$ and $s 5 \mathrm{HIH}^{+}(\mathrm{C} 4)-\mathrm{W}_{3}(\mathrm{OH}-\mathrm{W}-\mathrm{NH})$, the $\mathrm{H}$-bonds within the $\mathrm{W}_{2}$ chain at the $\mathrm{OH}$ group elongate from $R=1.560 / 1.733$ to $1.580 / 1.744 \AA$. The same trend is observed for all four interior solvated $s 5 \mathrm{HIH}^{+}-\mathrm{W}_{3}$ isomers (Fig. 4 and Table S1, ESI $\dagger$ ). In line with the weakening of the individual $\mathrm{H}$-bonds, for $n=3$ (interior solvation) the impact on the $s 5 \mathrm{HIH}^{+}$core is also weaker than for $n=2$ (water chain).
This directly translates into blue-shifts of the affected proton donor XH stretches. For instance, $\nu_{\mathrm{NH}}^{\mathrm{b}}$ of $s 5 \mathrm{HIH}^{+}(\mathrm{C} 3)-\mathrm{W}_{2}(\mathrm{NH}-\mathrm{W})$ and $s 5 \mathrm{HIH}^{+}(\mathrm{C} 3)-\mathrm{W}_{3}(\mathrm{OH}-\mathrm{NH}-\mathrm{W})$ are predicted at 2787 and $2834 \mathrm{~cm}^{-1}$, respectively.

Solvation of both $\mathrm{OH}$ groups of the oxonium ion yields $s 5 \mathrm{HIH}^{+}(\mathrm{O})-\mathrm{W}_{3}(\mathrm{OH}-\mathrm{OH}-\mathrm{W} 1)$ and $s 5 \mathrm{HIH}^{+}(\mathrm{O})-\mathrm{W}_{3}(\mathrm{OH}-\mathrm{OH}-\mathrm{W} 2)$ isomers with $D_{0}=229.2$ and $231.5 \mathrm{~kJ} \mathrm{~mol}^{-1}$, respectively. The latter is again stabilized by its additional interaction with the aromatic $\pi$-electron cloud. $\mathrm{A} \mathrm{W}_{2}$ chain is attached to one $\mathrm{OH}$ site, significantly elongating the affected $\mathrm{OH}$ bond $\left(r_{\mathrm{OH}}=1.068\right.$ and $1.104 \AA)$. The $\mathrm{OH} \cdots \mathrm{W}$ bond is still longer $(R=1.391$ and $1.330 \AA$ ). Hence, in contrast to what has been predicted for the corresponding $s 5 \mathrm{HIH}^{+}(\mathrm{O})-\mathrm{W}_{2}(\mathrm{OH}-\mathrm{W} 1)$ and $s 5 \mathrm{HIH}^{+}(\mathrm{O})-\mathrm{W}_{2}(\mathrm{OH}-\mathrm{W} 2)$ clusters, the proton is not transferred due to the noncooperative character of this $\mathrm{W}_{3}$ binding motif. However, proton-transferred structures cannot be neglected for $n=3$. We find four protontransferred structures, namely, $s 5 \mathrm{HIH}^{+}(\mathrm{O})-\mathrm{W}_{3}(\mathrm{NH}-\mathrm{OH}-\mathrm{W} 1 / \mathrm{W} 2)$ with a $\mathrm{W}_{2}$ chain at one $\mathrm{OH}$ group and a single $\mathrm{W}$ at the $\mathrm{NH}$ group as well as $s 5 \mathrm{HIH}^{+}(\mathrm{O})-\mathrm{W}_{3}(\mathrm{OH}-\mathrm{W}-\mathrm{W} 1 / \mathrm{W} 2)$ with a $\mathrm{W}_{3}$ chain at its $\mathrm{OH}$ group (Fig. 4 and Fig. S15, ESI $\dagger$ ). Interestingly, $s 5 \mathrm{HIH}^{+}(\mathrm{O})-\mathrm{W}_{3}(\mathrm{OH}-\mathrm{W}-\mathrm{W} 2)$ is the most stable structure found with $D_{0}=231.8 \mathrm{~kJ} \mathrm{~mol}^{-1}$. The $\mathrm{W}_{3}$ chain is entirely detached from the $\mathrm{OH}$ group $\left(r_{\mathrm{OH}}=1.763\right.$ and $\left.R_{\mathrm{OH}-\mathrm{W}}=0.985 \AA\right)$, and is arranged over the phenol ring of neutral $5 \mathrm{HI}$ (Fig. 4). This isomer is distinguished by its $\nu_{\mathrm{OH}}^{\mathrm{f}}$ and $\nu_{\mathrm{NH}}^{\mathrm{f}}$ predicted at 3633 and $3497 \mathrm{~cm}^{-1}$, and three intense $\nu_{\mathrm{OH}}^{\mathrm{b}(\mathrm{W})}$ at 3300, 3243, and $2806 \mathrm{~cm}^{-1}$. The other three structures are significantly less stable with $D_{0}=201.9,208.8$, and $216.5 \mathrm{~kJ} \mathrm{~mol}^{-1}$, respectively.

Fig. 6 compares the IRPD spectrum of $5 \mathrm{HIH}^{+}-\mathrm{W}_{3}$ to the calculated IR spectra of selected $s 5 \mathrm{HIH}^{+}-\mathrm{W}_{3}$ isomers. Spectra calculated for some additional $s / a 5 \mathrm{HIH}^{+}-\mathrm{W}_{3}$ conformers are given in Fig. S17 (ESI $\dagger$ ). The triplet A, G, and B at 3725, 3692, and $3637 \mathrm{~cm}^{-1}$ unambiguously reveals the predominance of chainlike $\mathrm{W}_{2}$ and/or $\mathrm{W}_{3}$ solvation structures. Band $\mathrm{A}$ is thus assigned to $\nu_{3}$, band $\mathrm{B}$ to $\nu_{1}$, and band $\mathrm{G}$ to $\nu_{\mathrm{OH}}^{\mathrm{f}(\mathrm{W})}$ of the singledonor water molecules. Candidates to explain this pattern are at least the isomers considered in Fig. 6, except for $s 5 \mathrm{HIH}^{+}(\mathrm{C} 3)-$ $\mathrm{W}_{3}(\mathrm{~W}-\mathrm{NH}-\mathrm{W})$ with a bifurcated $\mathrm{H}$-bond. However, a clear isomer assignment is challenging, because the IRPD spectrum is not well resolved below $3600 \mathrm{~cm}^{-1}$, possibly due to overlapping transitions of several isomers. Still, we can draw some conclusions from the comparison with the IRPD spectra of $5 \mathrm{HIH}^{+}-\mathrm{W}_{1 / 2}$ (Fig. 1). First, band $\mathrm{X}$ at $3508 \mathrm{~cm}^{-1}$ is considered to be a contamination band. It is not convincingly rationalized by any calculated mode and it occurs at the same position as band $\mathrm{X}$ in the spectrum of $5 \mathrm{HIH}^{+}-\mathrm{W}-\mathrm{N}_{2}(\mathrm{ESI} \dagger)$. Yet, one may argue that $\nu_{\mathrm{NH}}^{\mathrm{f}}$ of $s 5 \mathrm{HIH}^{+}(\mathrm{O})-$ $\mathrm{W}_{3}(\mathrm{NH}-\mathrm{OH}-\mathrm{W} 1 / \mathrm{W} 2)$ predicted at $3497 / 3500 \mathrm{~cm}^{-1}$ gives rise to band $\mathrm{X}$. However, already for $5 \mathrm{HIH}^{+}-\mathrm{W}_{2}$ it remains unclear whether oxonium clusters are probed. Any other modes of $s 5 \mathrm{HIH}^{+}(\mathrm{O})-\mathrm{W}_{3}(\mathrm{NH}-\mathrm{OH}-\mathrm{W} 1 / \mathrm{W} 2)$ are also not clearly observed. Second, bands $\mathrm{H}$ and $\mathrm{J}$ at 3360 and $3230 \mathrm{~cm}^{-1}$ can be related to corresponding transitions in the IRPD spectra of $5 \mathrm{HIH}^{+}-\mathrm{W}_{1 / 2}$. In analogy to the spectrum of $5 \mathrm{HIH}^{+}-\mathrm{W}_{2}$, band $\mathrm{H}$ may be assigned to $\nu_{\mathrm{OH}}^{\mathrm{b}(\mathrm{W})}$ of the solvated water and/or $\nu_{\mathrm{OH}}^{\mathrm{b}}$ of the $5 \mathrm{HIH}^{+}(\mathrm{C} 3)$ protomer. Corresponding transitions are predicted at 3225 and $3301 \mathrm{~cm}^{-1}$ for $s 5 \mathrm{HIH}^{+}(\mathrm{C} 3)-\mathrm{W}_{3}(\mathrm{OH}-\mathrm{NH}-\mathrm{W})$. In the 


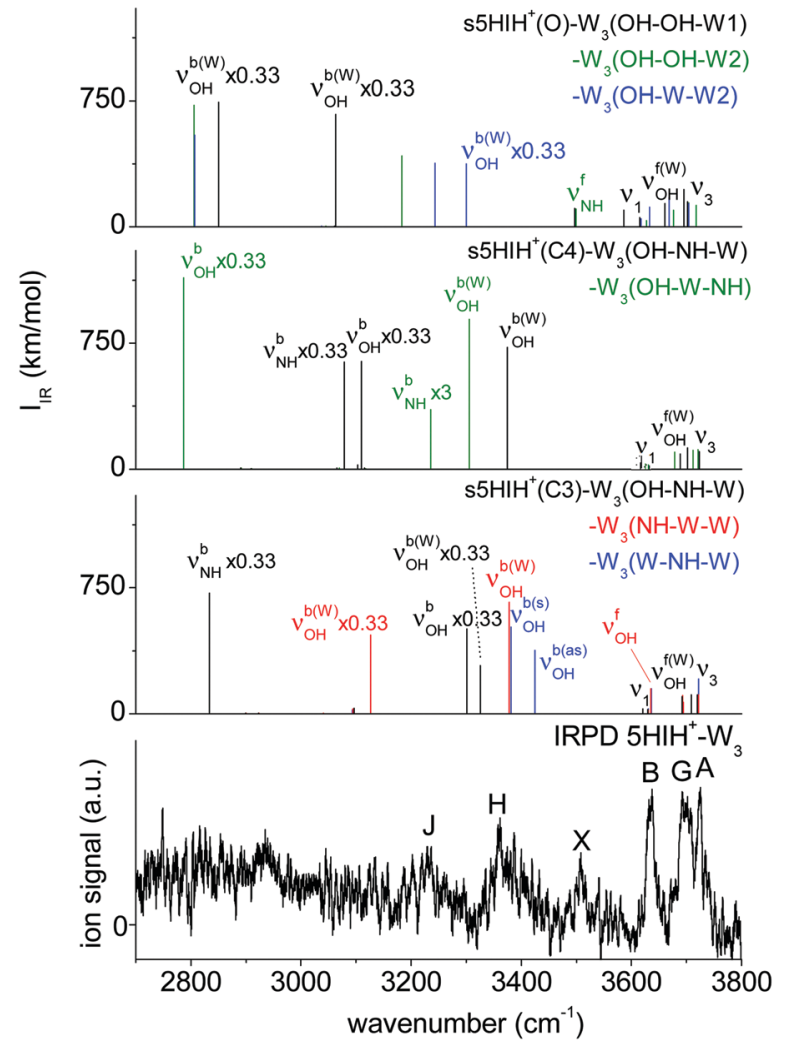

Fig. 6 Comparison of the IRPD spectrum of $5 \mathrm{HIH}^{+}-\mathrm{W}_{3}$ to calculated IR spectra of the relevant isomers at the B3LYP-D3/aug-cc-pVTZ level.

case of $5 \mathrm{HIH}^{+}-\mathrm{W}_{2}$, band $\mathrm{J}$ is assigned to $\nu_{\mathrm{NH}}^{\mathrm{b}}$ of the $5 \mathrm{HIH}^{+}(\mathrm{C} 4)$ core. The corresponding intense $\nu_{\mathrm{NH}}^{\mathrm{b}}$ mode of $s 5 \mathrm{HIH}^{+}(\mathrm{C} 4)-$ $\mathrm{W}_{3}(\mathrm{OH}-\mathrm{W}-\mathrm{NH})$ is predicted at $3236 \mathrm{~cm}^{-1}$. Bands $\mathrm{J}$ and $\mathrm{H}$ may also be explained by the two intense $\nu_{\mathrm{OH}}^{\mathrm{b}(\mathrm{W})}$ of the very stable proton-transferred $s 5 \mathrm{HIH}^{+}(\mathrm{O})-\mathrm{W}_{3}(\mathrm{OH}-\mathrm{W}-\mathrm{W} 2)$ oxonium isomer, which are predicted at 3300 and $3243 \mathrm{~cm}^{-1}$. Still, the IRPD spectrum of $5 \mathrm{HIH}^{+}-\mathrm{W}_{3}$ is already well reproduced by the two most stable carbenium ions $55 \mathrm{HIH}^{+}(\mathrm{C} 3)-\mathrm{W}_{3}(\mathrm{OH}-\mathrm{NH}-\mathrm{W})$ and $s 5 \mathrm{HIH}^{+}(\mathrm{C} 4)-\mathrm{W}_{3}(\mathrm{OH}-\mathrm{W}-\mathrm{NH})$. Finally, probably due to overlapping bands of several isomers, the spectral resolution is not sufficient to definitely exclude any of the isomers considered in Fig. 6 based on their IR spectra. A suggested, detailed assignment of the observed bands to vibrational modes and isomers is listed in Table 1. We most likely do not observe proton-transferred structures for $n=3$, or at most only at low percentage. To unambiguously evidence whether proton transfer happens at $n=3$ or not, the isomer contribution must be disentangled more accurately by double-resonance spectroscopy.

\subsection{Comparison to $5 \mathrm{HIH}^{+}-\mathrm{L}_{n}\left(\mathrm{~L}=\mathrm{Ar}, \mathrm{N}_{2}\right)$}

Recently, we studied the sequential microsolvation of $5 \mathrm{HIH}^{+}$ with nonpolar $(\mathrm{L}=\mathrm{Ar})$ and quadrupolar $\left(\mathrm{L}=\mathrm{N}_{2}\right)$ solvents. ${ }^{17}$ The IRPD spectra of the $5 \mathrm{HIH}^{+}-\mathrm{L}$ clusters with $\mathrm{L}=\mathrm{Ar}, \mathrm{N}_{2}$, and $\mathrm{W}$ are compared in Fig. S18 (ESI $\dagger$ ).

The same protomers have been identified in the $5 \mathrm{HIH}^{+}-\mathrm{L}_{n}$ clusters, namely, C3, C4 and O. C4-Protonation significantly affects the adjacent $\mathrm{OH}$ group. As a result, $s$ - and $a 5 \mathrm{HIH}^{+}(\mathrm{C} 4)$ rotamers are distinguishable by their well-resolved $\nu_{\mathrm{OH}}^{\mathrm{f}}$ bands appearing in the spectra of $5 \mathrm{HIH}^{+}-\mathrm{Ar}$ and $5 \mathrm{HIH}^{+}-\mathrm{N}_{2}$. In contrast, the current $5 \mathrm{HIH}^{+}-\mathrm{W}_{n}$ spectra are not sufficiently well resolved to distinguish $s$ - and $a 5 \mathrm{HIH}^{+}$rotamers. O-Protomers have unambiguously been identified by the IRPD spectra of larger $5 \mathrm{HIH}^{+}-$ $\left(\mathrm{N}_{2}\right)_{2 / 3}$ clusters recorded in different fragmentation channels. ${ }^{17}$ While the IRPD spectra measured in the $n \rightarrow 0$ loss channel correspond to the superposition of all three protomers, $2 \rightarrow 1$ and $3 \rightarrow 2$ loss channels provide the isomer-pure spectrum of O-protonated $5 \mathrm{HIH}^{+}(\mathrm{O})-\left(\mathrm{N}_{2}\right)_{2 / 3}$ clusters.

In general, the growth of $5 \mathrm{HIH}^{+}-\mathrm{L}_{n}$ clusters $\left(\mathrm{L}=\mathrm{Ar}, \mathrm{N}_{2}, \mathrm{~W}\right)$ follows similar trends. Our previous study related the acidity of the functional groups to the charge distribution in the individual protomers. ${ }^{17}$ In $5 \mathrm{HIH}^{+}(\mathrm{C} 3)$ the $\mathrm{NH}$ group is most acidic, whereas in $5 \mathrm{HIH}^{+}(\mathrm{C} 4)$ it is the $\mathrm{OH}$ group. For the oxonium, exclusively $\mathrm{H}$-bonding to its $\mathrm{OH}_{2}$ group is observed due to its high binding energies of $D_{0}=15.2(\mathrm{Ar}), 29.8\left(\mathrm{~N}_{2}\right)$, and $99.3(\mathrm{~W}) \mathrm{kJ} \mathrm{mol}^{-1}$ compared to only $D_{0}=5.5(\mathrm{Ar}), 9.3\left(\mathrm{~N}_{2}\right)$, and $39.5(\mathrm{~W}) \mathrm{kJ} \mathrm{mol}^{-1}$ for the NH-bound minimum. H-bonding and $\pi$-stacking compete in the growth of $5 \mathrm{HIH}^{+}-\mathrm{Ar}_{n}$ clusters. In contrast, the microsolvation of $5 \mathrm{HIH}^{+}$with $\mathrm{N}_{2}$ is dominated by $\mathrm{H}$-bonding to the functional groups instead of $\pi$-stacking, and the same is true for microhydration with $\mathrm{W}$. The $\mathrm{L}-\mathrm{L}$ interaction is rather small for both $\mathrm{Ar}$ and $\mathrm{N}_{2}\left(\sim 100 \mathrm{~cm}^{-1}\right),{ }^{54,55}$ because it relies mainly on dispersion. Hence, their $5 \mathrm{HIH}^{+}-\mathrm{L}_{n}$ clusters strongly prefer interior ion solvation over the formation of solvent networks. In contrast, the permanent dipole moment of $\mathrm{W}$ promotes the formation of water networks as the $\mathrm{W}-\mathrm{W}$ interaction is rather strong $\left(\sim 1000 \mathrm{~cm}^{-1}\right) .{ }^{42,51,52}$ Upon network formation, strong cooperative effects strengthen preexisting H-bonds, in particular in the presence of a positive charge. Indeed, the formation of $\mathrm{W}_{2}$ and $\mathrm{W}_{3}$ chains is indicated by the characteristic triplet of $\nu_{3}, \nu_{\mathrm{OH}}^{\mathrm{f}(\mathrm{W})}$, and $\nu_{1}$ in the IRPD spectra of $5 \mathrm{HIH}^{+}-\mathrm{W}_{2 / 3}$. Complexation-induced frequency red-shifts $\left(\Delta \nu_{\mathrm{XH}}\right)$ of H-bonded proton donor stretching modes are a convenient measure of intermolecular H-bond strengths. Therefore, we evaluate the $\Delta \nu_{\mathrm{OH}}^{\mathrm{b}}$ and $\Delta \nu_{\mathrm{NH}}^{\mathrm{b}}$ red-shifts (Table 2) observed in $5 \mathrm{HIH}^{+}-\mathrm{L}$ dimers as a function of the ligand $\left(\mathrm{L}=\mathrm{Ar}, \mathrm{N}_{2}, \mathrm{~W}\right)$. Fig. S19 (ESI $\dagger$ ) illustrates the dependence of the $\Delta \nu_{\mathrm{OH}}^{\mathrm{b}}$ and $\Delta \nu_{\mathrm{NH}}^{\mathrm{b}}$ red-shifts on the PAs of the ligands. ${ }^{6}$ Generally, the impact on the proton donor group increases monotonically in the order $\mathrm{Ar}<\mathrm{N}_{2}<\mathrm{W}$. The $\Delta \nu_{\mathrm{OH}}^{\mathrm{b}}$ red-shifts are larger than the $\Delta \nu_{\mathrm{NH}}^{\mathrm{b}}$ ones. However, one must be careful with their direct comparison because only for $s / a 5 \mathrm{HIH}^{+}(\mathrm{C} 4)$ both $\Delta \nu_{\mathrm{OH}}^{\mathrm{b}}$ and $\Delta \nu_{\mathrm{NH}}^{\mathrm{b}}$ are observed (Table 2). Our previous IRPD study of $5 \mathrm{HIH}^{+}-\mathrm{Ar} / \mathrm{N}_{2}$ already revealed an increase of the acidity of the $\mathrm{OH}$ group in the order $s 5 \mathrm{HIH}^{+}(\mathrm{C} 3)<a 5 \mathrm{HIH}^{+}(\mathrm{C} 4)<s 5 \mathrm{HIH}^{+}(\mathrm{C} 4)<s / a 5 \mathrm{HIH}^{+}(\mathrm{O}) .^{17}$ Indeed, complexation has the largest impact on the $\mathrm{OH}$ group of $s / a 5 \mathrm{HIH}^{+}(\mathrm{O})-\mathrm{L}$, which is the strongest $\mathrm{H}$-bond donor with $D_{0}=15.2,29.8$, and $61.8 \mathrm{~kJ} \mathrm{~mol}^{-1}$ for Ar, $\mathrm{N}_{2}$, and $\mathrm{W}$, respectively.

\subsection{Comparison to neutral $5 \mathrm{HI}-\mathrm{W}$ and cationic $5 \mathrm{HI}^{+}-\mathrm{W}_{n}$}

A direct comparison of the (structural) properties of neutral $5 \mathrm{HI}-\mathrm{W}$ and cationic $5 \mathrm{HI}^{+}-\mathrm{W}$ to the protonated $5 \mathrm{HIH}^{+}-\mathrm{W}$ clusters is challenging because protonation strongly affects the chemical structure. While only two isomers, namely, syn and anti rotamers, exist in the $\mathrm{S}_{0}$ and $\mathrm{D}_{0}$ states of $5 \mathrm{HI}^{(+)}$, we observe (at least) six 
Table 2 Observed frequencies of the proton donor stretching modes $\left(\nu_{\mathrm{XH}}, \mathrm{X}=\mathrm{N} / \mathrm{O}\right.$, in $\left.\mathrm{cm}^{-1}\right)$ of $5 \mathrm{HIH}^{+}$and $\mathrm{PhH}^{+}$and corresponding complexation-induced frequency red shifts $\left(\Delta \nu_{\mathrm{XH}}\right)$ in $5 \mathrm{HIH}^{+} / \mathrm{PhH}^{+}-\mathrm{L}$ clusters $\left(L=A r, N_{2}, W\right)$

\begin{tabular}{|c|c|c|c|c|}
\hline \multirow[b]{2}{*}{ Isomer } & \multirow[b]{2}{*}{$\nu_{\mathrm{XH}}$} & \multicolumn{3}{|l|}{$\Delta \nu_{\mathrm{XH}}$} \\
\hline & & $\mathrm{L}=\mathrm{Ar}$ & $\mathrm{L}=\mathrm{N}_{2}$ & $\mathrm{~L}=\mathrm{W}$ \\
\hline $\mathrm{PhH}^{+}(\mathrm{O})$ & $\begin{array}{l}3552(\mathrm{X}=\mathrm{O})^{a} \\
3477(\mathrm{X}=\mathrm{O})^{a}\end{array}$ & $\begin{array}{l}-18^{a} \\
-148^{a}\end{array}$ & $\begin{array}{l}-9^{a} \\
-440^{a}\end{array}$ & $\begin{array}{l}+33^{d} \\
>-877^{d}\end{array}$ \\
\hline $\mathrm{PhH}^{+}(o / p)$ & $3554(\mathrm{X}=\mathrm{O})^{b}$ & -61 & -146 & -654 \\
\hline$a / s 5 \mathrm{HIH}^{+}(\mathrm{O})$ & $\begin{array}{l}3555(\mathrm{X}=\mathrm{O})^{c} \\
3480(\mathrm{X}=\mathrm{O})^{c} \\
3503(\mathrm{X}=\mathrm{N})\end{array}$ & $\begin{array}{l}-20 \\
-115 \\
\text { Not observed }\end{array}$ & $\begin{array}{l}-15 \\
-335 \\
\text { Not observed }\end{array}$ & $\begin{array}{l}+36 \\
-1304^{c} \\
\text { Not observed }\end{array}$ \\
\hline$s 5 \mathrm{HIH}^{+}(\mathrm{C} 3)$ & $3635(\mathrm{X}=\mathrm{O})$ & $\begin{array}{l}\text { Not observed } \\
-40\end{array}$ & $\begin{array}{l}\text { Not observed } \\
-65\end{array}$ & $\begin{array}{l}\text { Not observed } \\
-390\end{array}$ \\
\hline$a 5 \mathrm{HIH}^{+}(\mathrm{C} 4)$ & $\begin{array}{l}3598(\mathrm{X}=\mathrm{O}) \\
3478(\mathrm{X}=\mathrm{N})\end{array}$ & $\begin{array}{l}-63 \\
-24\end{array}$ & $\begin{array}{l}-118 \\
-68\end{array}$ & $\begin{array}{l}-583 \\
-348\end{array}$ \\
\hline$s 5 \mathrm{HIH}^{+}(\mathrm{C} 4)$ & $\begin{array}{l}3584(\mathrm{X}=\mathrm{O}) \\
3478(\mathrm{X}=\mathrm{N})\end{array}$ & $\begin{array}{l}-49 \\
-13\end{array}$ & $\begin{array}{l}-131 \\
-68\end{array}$ & $\begin{array}{l}-569 \\
-348\end{array}$ \\
\hline
\end{tabular}

${ }^{a}$ Values correspond to Ne-tagged $\mathrm{PhH}^{+}(\mathrm{O})-\mathrm{Ne}(\mathrm{OH}),{ }^{20}$ which closely approximate those of bare $\mathrm{PhH}^{+}(\mathrm{O})$. Complexation-induced red-shifts are calculated relative to $\mathrm{PhH}^{+}(\mathrm{O})-\mathrm{Ne}(\mathrm{OH}) \cdot{ }^{b}$ Value corresponds to $\pi$-bonded $\mathrm{PhH}^{+}(o / p)-\operatorname{Ar}(\pi),{ }^{20}$ which closely approximates that of bare $\mathrm{PhH}^{+}(o / p) .{ }^{c}$ Values calculated at the B3LYP-D3/aug-cc-pVTZ level. ${ }^{d}$ Values taken from ref. 14.

protomers for $5 \mathrm{HIH}^{+}$, namely, $s / a 5 \mathrm{HIH}^{+}(\mathrm{C} 3), s / a 5 \mathrm{HIH}^{+}(\mathrm{C} 4)$, and $s / a 5 \mathrm{HIH}^{+}(\mathrm{O})$.

In the neutral ground state $\left(\mathrm{S}_{0}\right), \mathrm{NH}^{-}$and $\mathrm{OH}-$ bound hydrates of both $s$ - and $a 5 \mathrm{HI}$ rotamers could be identified by isomer-selective IR spectroscopy. ${ }^{56}$ While neutral $a 5 \mathrm{HI}-\mathrm{W}$ clusters are more stable by $\Delta E_{0}>1.1 \mathrm{~kJ} \mathrm{~mol}^{-1}$, protonation reverses this trend, such that protonated $s 5 \mathrm{HIH}^{+}-\mathrm{W}$ are more stable by $\Delta E_{0}>$ $1.5 \mathrm{~kJ} \mathrm{~mol}^{-1}$. In the $\mathrm{S}_{0}$ state, $\mathrm{OH} \cdots \mathrm{W}$ bonds are stronger than $\mathrm{NH} \cdots \mathrm{W}$ bonds. Upon C3-protonation the neutral $\mathrm{NH} \cdots \mathrm{W}$ bond is strengthened from $D_{\mathrm{e}}=40.2$ to $88.6 \mathrm{~kJ} \mathrm{~mol}^{-1.5}$. The strengthening of the $\mathrm{OH} \cdots \mathrm{W}$ bond is less pronounced with $D_{\mathrm{e}}=43.3 v \mathrm{~s}$. $76.8 \mathrm{~kJ} \mathrm{~mol}^{-1}$. $^{5}$ These results were rationalized by the large charge density on the pyrrole ring of $5 \mathrm{HIH}^{+}(\mathrm{C} 3)$, which affects the acidity of the $\mathrm{OH}$ and $\mathrm{NH}$ groups. Our recent analysis of the NBO charge distribution in $5 \mathrm{HIH}^{+}(\mathrm{C} 3), 5 \mathrm{HIH}^{+}(\mathrm{C} 4)$, and $5 \mathrm{HIH}^{+}(\mathrm{O})$ quantifies this qualitative argument. ${ }^{17}$

The IRPD spectrum of $5 \mathrm{HI}^{+}-\mathrm{W}$ is depicted in Fig. 3. Number and positions of the bands $(\mathrm{A}-\mathrm{F})$ are similar to those observed for $5 \mathrm{HIH}^{+}-\mathrm{W}$, indicating comparable structures of the $5 \mathrm{HI}$ core and similar microhydration motifs ( $\mathrm{OH} \cdots \mathrm{W}$ and $\mathrm{NH} \cdots \mathrm{W}$ H-bonds). However, band widths and intensities differ significantly. The spectrum of $5 \mathrm{HI}^{+}-\mathrm{W}$ was explained by the coexistence of $5 \mathrm{HI}^{+}-\mathrm{W}(\mathrm{OH})$ and $5 \mathrm{HI}^{+}-\mathrm{W}(\mathrm{NH}){ }^{23}$ Also in the cationic ground state $\left(\mathrm{D}_{0}\right), \mathrm{OH} \cdots \mathrm{W}$ bonds are stronger than $\mathrm{NH} \cdots \mathrm{W}$ bonds, yet the interaction strengths are significantly enhanced compared to the neutral clusters. Hence, $\mathrm{OH} \cdots \mathrm{W}$ bonds are strongly preferred over $\mathrm{NH} \cdots \mathrm{W}$ bonds by a factor of $10{ }^{23}$ A very rough estimate of the population of the $5 \mathrm{HIH}^{+}-\mathrm{W}$ protomers yields that $5 \mathrm{HIH}^{+}(\mathrm{C} 3)-\mathrm{W}(\mathrm{NH})$ and $5 \mathrm{HIH}^{+}(\mathrm{C} 4)-\mathrm{W}(\mathrm{OH})$ contribute $\approx 70 \%$, $5 \mathrm{HIH}^{+}(\mathrm{C} 4)-\mathrm{W}(\mathrm{NH}) \approx 20 \%$, and $5 \mathrm{HIH}^{+}(\mathrm{O})-\mathrm{W}(\mathrm{OH}) \approx 10 \%$. Thus, due to the strong variation of the acidity of the $\mathrm{NH}$ and $\mathrm{OH}$ groups upon protonation, there is no longer any preference for $\mathrm{OH} \cdots \mathrm{W}$ or $\mathrm{NH} \cdots \mathrm{W}$ bonds. In the $\mathrm{D}_{0}$ state, clusters of $s 5 \mathrm{HI}^{+}$are more stable than those of $a 5 \mathrm{HI}^{+}$, and the same is true for the protonated species.
IRPD spectroscopy of $5 \mathrm{HI}^{+}-\mathrm{W}_{n}$ clusters reveals the competition between interior ion solvation and the formation of H-bonded water networks. ${ }^{23}$ For $5 \mathrm{HI}^{+}-\mathrm{W}_{2}$, interior ion solvation at both acidic groups $(\mathrm{OH} / \mathrm{NH})$ is strongly preferred $(\geq 90 \%)$. For $5 \mathrm{HI}^{+}-\mathrm{W}_{3}$, two isomers coexist which bear one single $\mathrm{W}$ and one $\mathrm{W}_{2}$ dimer $\mathrm{H}$-bonded to either of the functional groups. The IRPD spectrum of $5 \mathrm{HI}^{+}-\mathrm{W}_{3}$ suggests a strong preference for attachment of the $\mathrm{W}_{2}$ dimer at the $\mathrm{OH}$ group, leading to an estimated population ratio of $10: 1$ for $\mathrm{OH} / \mathrm{W} / \mathrm{NH}: \mathrm{OH} / \mathrm{NH} / \mathrm{W}^{23}$ Proton transfer from $5 \mathrm{HI}^{+}-\mathrm{W}_{n}$ to the solvent was not observed for $n \leq 3$. These results are in line with our current findings on the $5 \mathrm{HIH}^{+}-\mathrm{W}_{n}$ clusters.

\subsection{Comparison to $\mathrm{PhH}^{+}-\mathrm{W}_{n}$}

It is instructive to compare our results for $5 \mathrm{HIH}^{+}-\mathrm{W}_{n}$ to those obtained by IRPD spectroscopy of the related $\mathrm{PhH}^{+}-\mathrm{W}_{n}$ clusters because (i) similar protonation mechanisms have been evidenced for $\mathrm{PhH}^{+}$, resulting in carbenium $\mathrm{PhH}^{+}(p / o)$ and oxonium $\mathrm{PhH}^{+}(\mathrm{O})$ ions, ${ }^{14,18-20,24}$ and (ii) as a consequence, the microhydration is expected to be similar. In our previous study, ${ }^{17}$ we compared the protonation of $5 \mathrm{HIH}^{+}$and $\mathrm{PhH}^{+}$and their microsolvation by $\mathrm{Ar}$ and $\mathrm{N}_{2}$, revealing that the acidity of the $\mathrm{OH}$ group increases as $s 5 \mathrm{HIH}^{+}(\mathrm{C} 3)<a 5 \mathrm{HIH}^{+}(\mathrm{C} 4)<s 5 \mathrm{HIH}^{+}(\mathrm{C} 4)<$ $\mathrm{PhH}^{+}(p / o)<s 5 \mathrm{HIH}^{+}(\mathrm{O})<a 5 \mathrm{HIH}^{+}(\mathrm{O})<\mathrm{PhH}^{+}(\mathrm{O}) .{ }^{17}$ The acidity of the functional group(s) correlates with the H-bond strength and is crucial for proton transfer.

The IRPD spectra of $\mathrm{PhH}^{+}-\mathrm{W}_{n}$ with $n \leq 5$ were interpreted by $\mathrm{PhH}^{+}(p / o)-\mathrm{W}_{n}$ and $\mathrm{PhH}^{+}(\mathrm{O})-\mathrm{W}_{n}$ clusters, for which proton transfer occurs at different critical sizes of the hydration shell $\left(n_{\mathrm{c}}\right)$. In the case of $\mathrm{PhH}^{+}(\mathrm{O})-\mathrm{W}_{n}$, the critical size is determined as $n_{\mathrm{c}}=3$, and for $\mathrm{PhH}^{+}(o / p)-\mathrm{W}_{n}$ as $n_{\mathrm{c}}=4 .{ }^{14}$ Most likely, the transferred proton is the excess proton, coming from the $\mathrm{OH}_{2}$ group of $\mathrm{PhH}^{+}(\mathrm{O})$ and the $\mathrm{CH}_{2}$ group of $\mathrm{PhH}^{+}(p / o)$. However, for all $\mathrm{PhH}^{+}-\mathrm{W}_{n}$ exclusively the $\mathrm{OH}$ group is solvated. Hence, the $\mathrm{W}_{n}$ network has to bridge the $\mathrm{OH}$ group and the protonated $\mathrm{CH}_{2}$ group in $\mathrm{PhH}^{+}(p / o)$ which is only possible for $\mathrm{W}_{n \geq 4}$ chains. Our current IRPD spectra of $5 \mathrm{HIH}^{+}-\mathrm{W}_{n}$ do not indicate proton transfer at $n \leq 3$ for any of the assigned protomers. This finding is interesting as we also observe hydrated oxonium ions, $5 \mathrm{HIH}^{+}(\mathrm{O})-\mathrm{W}_{n}$. To elucidate the microsolvation mechanism, we compare the acidity of the $\mathrm{OH}$ groups of $\mathrm{PhH}^{+}(o / p)$ and $\mathrm{PhH}^{+}(\mathrm{O})$ to those of the observed $5 \mathrm{HIH}^{+}(\mathrm{C} 3), 5 \mathrm{HIH}^{+}(\mathrm{C} 4)$, and $5 \mathrm{HIH}^{+}(\mathrm{O})$ clusters with the aid of the measured complexationinduced red-shifts of the $\mathrm{OH}$ stretch $\left(\Delta \nu_{\mathrm{OH}}\right)$ (Table 2). Most obviously, the acidity of the $\mathrm{OH}$ group of $5 \mathrm{HIH}^{+}(\mathrm{C} 3)$ is the smallest, because its $\nu_{\mathrm{OH}}$ has the highest measured frequency $\left(3635 \mathrm{~cm}^{-1}\right),{ }^{17}$ and we do not observe $\mathrm{OH} \cdots \mathrm{W}$ bonds for $5 \mathrm{HIH}^{+}(\mathrm{C} 3)-\mathrm{W}$. Preferentially, $s / a 5 \mathrm{HIH}^{+}(\mathrm{C} 4)$ are solvated at the $\mathrm{OH}$ group, yet the observed $\Delta \nu_{\mathrm{OH}}$ shifts are of medium size $\left(\Delta \nu_{\mathrm{OH}}=-569 /-583 \mathrm{~cm}^{-1}\right)$. The $\mathrm{OH} \cdots \mathrm{W}$ H-bond in $\mathrm{PhH}^{+}(o / p)-\mathrm{W}$ is comparably strong with $\Delta \nu_{\mathrm{OH}}=-654 \mathrm{~cm}^{-1}$. Unfortunately, $\Delta \nu_{\mathrm{OH}}$ has not been measured for $\mathrm{PhH}^{+}(\mathrm{O})-\mathrm{W},{ }^{14}$ but is estimated to be larger than $-877 \mathrm{~cm}^{-1}$. Hence, we determine the largest value of $\Delta \nu_{\mathrm{OH}}=-1304 \mathrm{~cm}^{-1}$ for $a / s 5 \mathrm{HIH}^{+}(\mathrm{O})-\mathrm{W}$. Considering the red-shifts induced by attachment of $\mathrm{Ar}$ and $\mathrm{N}_{2}$ at the $\mathrm{OH}$ group of $\mathrm{PhH}^{+}(\mathrm{O})$ and $5 \mathrm{HIH}^{+}(\mathrm{O})$, we again infer a somewhat 
larger acidity of the $\mathrm{OH}$ group of $\mathrm{PhH}^{+}(\mathrm{O}) \cdot{ }^{17}$ Hence, proton transfer may occur at $n_{\mathrm{c}} \geq 4$ for $5 \mathrm{HIH}^{+}(\mathrm{O})-\mathrm{W}_{n}$.

\section{Conclusions}

Herein, we investigate the initial microhydration of a prototypical protonated heteroaromatic biomolecule using IRPD spectroscopy of size-selected $5 \mathrm{HIH}^{+}-\mathrm{W}_{n}\left(\mathrm{~W}=\mathrm{H}_{2} \mathrm{O}, n=1-3\right)$ clusters in the $\mathrm{XH}$ stretching range and calculations at the B3LYP-D3/aug-cc-pVTZ level. Our results may be summarized as follows.

We observe clusters of the C3- and C4-protonated carbenium ions, $5 \mathrm{HIH}^{+}(\mathrm{C} 3)$ and $5 \mathrm{HIH}^{+}(\mathrm{C} 4)$, and the oxonium ion, $5 \mathrm{HIH}^{+}(\mathrm{O})$. Detection of $5 \mathrm{HIH}^{+}(\mathrm{O})-\mathrm{W}_{n}$ clusters is surprising at first glance because they are significantly less stable $\left(\Delta E_{0}>75 \mathrm{~kJ} \mathrm{~mol}^{-1}\right)$. However, the H-bonds to the protonated $\mathrm{OH}_{2}$ group are very strong $\left(D_{0}>99 \mathrm{~kJ} \mathrm{~mol}^{-1}\right)$. In line with our previous results obtained for $5 \mathrm{HIH}^{+}-\mathrm{L}$ with $\mathrm{L}=\mathrm{Ar}$ and $\mathrm{N}_{2},{ }^{17} 5 \mathrm{HIH}^{+}(\mathrm{O})-\mathrm{W}_{n}$ clusters benefit from the strong $\mathrm{OH} \cdots \mathrm{W}$ bond and the twofold degeneracy of the corresponding minimum. At the current spectral resolution, syn and anti rotamers $\left(s-\right.$ and $\left.a 5 \mathrm{HIH}^{+}\right)$are not distinguishable. As the energy differences between their clusters are rather small $\left(\Delta E_{0}=1-5 \mathrm{~kJ} \mathrm{~mol}^{-1}\right)$, we assume the production of both $s$ - and $a 5 \mathrm{HIH}^{+}-\mathrm{W}_{n}$ clusters.

$5 \mathrm{HIH}^{+}-\mathrm{W}_{n}$ grow by $\mathrm{H}$-bonding of the first $\mathrm{W}$ ligand to the acidic $\mathrm{NH}$ and $\mathrm{OH}$ groups, and $\pi$-stacking of $\mathrm{W}$ is unlikely. The absolute and relative strengths of the $\mathrm{NH} \cdots \mathrm{W}$ and $\mathrm{OH} \cdots \mathrm{W}$ $\mathrm{H}$-bonds strongly depend on the $5 \mathrm{HIH}^{+}$protomer. The strongest $\mathrm{H}$-bond is found in $5 \mathrm{HIH}^{+}(\mathrm{O})-\mathrm{W}(\mathrm{OH})$ with $\mathrm{W}$ attached to one of its $\mathrm{OH}$ groups with an outstandingly high binding energy of $D_{0}=99.3 \mathrm{~kJ} \mathrm{~mol}^{-1}$. The acidity of the $\mathrm{OH}$ group (NH group) increases (decreases) in the order $5 \mathrm{HIH}^{+}(\mathrm{C} 3)<5 \mathrm{HIH}^{+}(\mathrm{C} 4)<$ $5 \mathrm{HIH}^{+}(\mathrm{O}) .{ }^{17}$ Thus, we predominantly observe $5 \mathrm{HIH}^{+}(\mathrm{C} 3)-$ $\mathrm{W}(\mathrm{NH})$, both $5 \mathrm{HIH}^{+}(\mathrm{C} 4)-\mathrm{W}(\mathrm{NH})$ and $5 \mathrm{HIH}^{+}(\mathrm{C} 4)-\mathrm{W}(\mathrm{OH})$, and $5 \mathrm{HIH}^{+}(\mathrm{O})-\mathrm{W}(\mathrm{OH})$ clusters. IRPD spectra of tagged $5 \mathrm{HIH}^{+}-\mathrm{W}-$ $\mathrm{Ar} / \mathrm{N}_{2}$ clusters confirm this assignment. Interior ion solvation and formation of water networks compete for $5 \mathrm{HIH}^{+}-\mathrm{W}_{2}$. We assign carbenium clusters with both functional groups solvated, $s 5 \mathrm{HIH}^{+}(\mathrm{C} 3)-\mathrm{W}_{2}(\mathrm{NH}-\mathrm{OH})$ and $s 5 \mathrm{HIH}^{+}(\mathrm{C} 4)-\mathrm{W}_{2}(\mathrm{NH}-\mathrm{OH})$, and those with $\mathrm{W}_{2}$ water chains at their respective most acidic functional group, $s 5 \mathrm{HIH}^{+}(\mathrm{C} 3)-\mathrm{W}_{2}(\mathrm{NH}-\mathrm{W})$ and $s 5 \mathrm{HIH}^{+}(\mathrm{C} 4)-$ $\mathrm{W}_{2}(\mathrm{OH}-\mathrm{W})$. The IRPD spectrum of $5 \mathrm{HIH}^{+}-\mathrm{W}_{2}$ does not clearly show features of any $5 \mathrm{HIH}^{+}(\mathrm{O})-\mathrm{W}_{2}$ clusters. The spectrum of $5 \mathrm{HIH}^{+}-\mathrm{W}_{3}$ clearly indicates $\mathrm{W}_{2}$ water chains at the $\mathrm{NH}$ and $\mathrm{OH}$ groups. It can readily be explained by the two most stable carbenium ions, $s 5 \mathrm{HIH}^{+}(\mathrm{C} 3)-\mathrm{W}_{3}(\mathrm{OH}-\mathrm{NH}-\mathrm{W})$ and $s 5 \mathrm{HIH}^{+}(\mathrm{C} 4)-\mathrm{W}_{3}(\mathrm{OH}-\mathrm{W}-\mathrm{NH})$. Isomer $s 5 \mathrm{HIH}^{+}(\mathrm{C} 3)-\mathrm{W}_{3}(\mathrm{~W}-\mathrm{NH}-\mathrm{W})$ with a bifurcated $\mathrm{H}$-bond may also contribute to the measured spectrum. Again, we exclude the oxonium $5 \mathrm{HIH}^{+}(\mathrm{O})-\mathrm{W}_{3}$ clusters. Future IR-UV or IR-IR double resonance spectroscopy may facilitate disentangling the isomer contribution to the IRPD spectrum of $5 \mathrm{HIH}^{+}-\mathrm{W}_{n}$.

Compared to the growth of $5 \mathrm{HIH}^{+}-\mathrm{L}_{n}$ clusters $\left(\mathrm{L}=\mathrm{Ar}, \mathrm{N}_{2}\right)$, $\mathrm{H}$-bonding is strongly preferred for $\mathrm{L}=\mathrm{W}$, and $\mathrm{W}_{n}$ networks compete with interior ion solvation, which is not the case for $\mathrm{L}=\mathrm{Ar} / \mathrm{N}_{2}$. The strength of individual $\mathrm{H}$-bonds increases in the order $\mathrm{Ar}<\mathrm{N}_{2}<\mathrm{W}$ as shown by comparison of the respective complexation-induced frequency red-shifts $\left(\Delta \nu_{\mathrm{XH}}\right)$ of the corresponding $\mathrm{H}$-bonded proton donor stretching modes.

Protonation significantly strengthens the $\mathrm{OH} \cdots \mathrm{W}$ and $\mathrm{NH} \cdots \mathrm{W}$ H-bonds observed in neutral $5 \mathrm{HI}-\mathrm{W}$ due to the excess charge. ${ }^{5}$ The distribution of the excess positive charge is very different in the individual protomers directly affecting the acidity of the $\mathrm{OH}$ and $\mathrm{NH}$ groups. In the neutral $\mathrm{S}_{0}$ ground state, a5HI-W clusters are more stable than $s 5 \mathrm{HI}-\mathrm{W} .{ }^{56}$ In contrast, ionization into the $\mathrm{D}_{0}$ state and protonation reverse the relative stability of the rotamers. ${ }^{22,23}$ The mechanism of the growth of the initial solvation shell $(n<4)$ is very similar for cationic and protonated hydrates.

IRPD spectra of the $\mathrm{PhH}^{+}$subunit of $5 \mathrm{HIH}^{+}$revealed proton transferred at critical sizes $n_{\mathrm{c}}=3$ and 4 in the case of $\mathrm{PhH}^{+}(\mathrm{O})-$ $\mathrm{W}_{n}$ and $\mathrm{PhH}^{+}(o / p)-\mathrm{W}_{n}$, respectively. ${ }^{14}$ In contrast, we do not observe any clear characteristics of proton-transferred structures in the $5 \mathrm{HIH}^{+}-\mathrm{W}_{n}$ clusters up to $n=3$. Yet, we observe an increase in the acidity of the $\mathrm{OH}$ group in the order $5 \mathrm{HIH}^{+}(\mathrm{C} 3)<5 \mathrm{HIH}^{+}(\mathrm{C} 4)<$ $\mathrm{PhH}^{+}(p / o)<5 \mathrm{HIH}^{+}(\mathrm{O})<\mathrm{PhH}^{+}(\mathrm{O})$. Hence, proton transfer may occur at $n_{\mathrm{c}} \geq 4$ for $5 \mathrm{HIH}^{+}(\mathrm{O})-\mathrm{W}_{n}$.

\section{Conflicts of interest}

There are no conflicts to declare.

\section{Acknowledgements}

This study was supported by Deutsche Forschungsgemeinschaft (DO 729/3). J. K. is grateful for a fellowship of the Studienstiftung des deutschen Volkes.

\section{References}

1 A. T. Balaban, D. C. Oniciu and A. R. Katritzky, Chem. Rev., 2004, 104, 2777-2812.

2 J. M. Berg, J. L. Tymoczko and L. Stryer, Biochemistry, Freeman, New York, 2002.

3 J. P. Schermann, Spectroscopy and modeling of biomolecular building blocks, Elsevier, 2007.

4 H.-S. Andrei, N. Solcà and O. Dopfer, ChemPhysChem, 2006, 7, 107-110.

5 R. Omidyan, M. Omidyan and A. Mohammadzadeh, RSC Adv., 2016, 6, 33148-33158.

6 E. P. L. Hunter and S. G. Lias, J. Phys. Chem., 1998, 27, 413-656.

7 D. J. Goebbert and P. G. Wenthold, Eur. J. Mass Spectrom., 2004, 10, 837-845.

8 M. Miyazaki, A. Fujii, T. Ebata and N. Mikami, Chem. Phys. Lett., 2004, 399, 412-416.

9 E. S. Kryachko and M. T. Nguyen, J. Phys. Chem. A, 2001, 105, 153-155.

10 T. C. Cheng, B. Bandyopadhyay, J. D. Mosley and M. A. Duncan, J. Am. Chem. Soc., 2012, 134, 13046-13055.

11 I. Alata, M. Broquier, C. Dedonder-Lardeux, C. Jouvet, M. Kim, W. Y. Sohn, S. Kim, H. Kang, M. Schütz and A. Patzer, et al., J. Chem. Phys., 2011, 134, 74307. 
12 O. Dopfer, A. Patzer, S. Chakraborty, I. Alata, R. Omidyan, M. Broquier, C. Dedonder and C. Jouvet, J. Chem. Phys., 2014, 140, 124314.

13 O. Dopfer and M. Fujii, Chem. Rev., 2016, 116, 5432-5463.

14 M. Katada and A. Fujii, J. Phys. Chem. A, 2018, 122, 5822-5831.

15 K. Tanabe, M. Miyazaki, M. Schmies, A. Patzer, M. Schütz, H. Sekiya, M. Sakai, O. Dopfer and M. Fujii, Angew. Chem., Int. Ed., 2012, 51, 6604-6607.

16 M. Ataelahi and R. Omidyan, J. Phys. Chem. A, 2013, 117, 12842-12850.

17 J. Klyne and O. Dopfer, J. Phys. Chem. B, 2018, 122, 10700-10713. 18 N. Solcà and O. Dopfer, Chem. Phys. Lett., 2001, 342, 191-199.

19 N. Solcà and O. Dopfer, J. Chem. Phys., 2004, 120, 10470-10482.

20 N. Solcà and O. Dopfer, J. Am. Chem. Soc., 2004, 126, 1716-1725.

21 S. A. Nizkorodov, O. Dopfer, T. Ruchti, M. Meuwly, J. P. Maier and E. J. Bieske, J. Phys. Chem., 1995, 99, 17118-17129.

22 J. Klyne and O. Dopfer, J. Mol. Spectrosc., 2017, 337, 124-136.

23 J. Klyne, M. Miyazaki, M. Fujii and O. Dopfer, Phys. Chem. Chem. Phys., 2018, 20, 3092-3108.

24 N. Solcà and O. Dopfer, J. Chem. Phys., 2004, 121, 769-772.

25 O. Dopfer, Int. Rev. Phys. Chem., 2003, 22, 437-495.

26 O. Dopfer, Z. Phys. Chem., 2005, 219, 125-168.

27 M. J. Frisch, et al., GAUSSIANO9, Rev. D.01, Gaussian, Inc., Wallingford, CT, 2009.

28 J. Klyne, A. Bouchet, S. Ishiuchi, M. Fujii, M. Schneider, C. Baldauf and O. Dopfer, Phys. Chem. Chem. Phys., 2018, 20, 28452-28464.

29 W. Fu and W. S. Hopkins, J. Phys. Chem. A, 2017, 122, 167-171.

30 M. Rossi and C. Baldauf, J. Phys.: Condens. Matter, 2015, 27, 493002.

31 A. D. Becke, Phys. Rev. A: At., Mol., Opt. Phys., 1988, 38, 3098.

32 A. D. Becke, J. Chem. Phys., 1993, 98, 5648-5652.

33 C. Lee, W. Yang and R. G. Parr, Phys. Rev. B: Condens. Matter Mater. Phys., 1988, 37, 785.

34 T. H. Dunning, J. Chem. Phys., 1989, 90, 1007-1023.

35 M. Miyazaki, A. Naito, T. Ikeda, J. Klyne, K. Sakota, H. Sekiya, O. Dopfer and M. Fujii, Phys. Chem. Chem. Phys., 2018, 20, 3079-3091.
36 M. Schütz, Y. Matsumoto, A. Bouchet, M. Öztürk and O. Dopfer, Phys. Chem. Chem. Phys., 2017, 19, 3970-3986.

37 Q. Zhang and L. Du, Comput. Theor. Chem., 2016, 1078, 123-128.

38 H. Zhao, J. Chang and L. Du, Comput. Theor. Chem., 2016, 1084, 126-132.

39 S. Grimme, J. Antony, S. Ehrlich and H. Krieg, J. Chem. Phys., 2010, 132, 154104.

40 M. Miyazaki, A. Fujii and N. Mikami, J. Phys. Chem. A, 2004, 108, 8269-8272.

41 K. Chatterjee and O. Dopfer, Phys. Chem. Chem. Phys., 2017, 19, 32262-32271.

42 B. E. Rocher-Casterline, L. C. Ch'ng, A. K. Mollner and H. Reisler, J. Chem. Phys., 2011, 134, 211101.

43 K. Chatterjee and O. Dopfer, Chem. Sci., 2018, 9, 2301-2318. 44 C. Baldauf, K. Pagel, S. Warnke, G. von Helden, B. Koksch, V. Blum and M. Scheffler, Chem. - Eur. J., 2013, 19, 11224-11234. 45 V. Scutelnic, M. A. S. Perez, M. Marianski, S. Warnke, A. Gregor, U. Rothlisberger, M. T. Bowers, C. Baldauf, G. von Helden and T. R. Rizzo, et al., J. Am. Chem. Soc., 2018, 140, 7554-7560.

46 M. Ropo, M. Schneider, C. Baldauf and V. Blum, Sci. Data, 2016, 3, 160009.

47 S. Simon, M. Duran and J. J. Dannenberg, J. Chem. Phys., 1996, 105, 11024-11031.

48 S. F. Boys and F. Bernardi, Mol. Phys., 1970, 19, 553-566.

49 G. Herzberg, Molecular spectra and molecular structure, Read Books Ltd, 2013.

50 V. Barone, J. Chem. Phys., 2004, $122,14108$.

51 J. Klyne, M. Schmies, M. Miyazaki, M. Fujii and O. Dopfer, Phys. Chem. Chem. Phys., 2018, 20, 3148-3164.

52 J. Klyne, M. Schmies, M. Fujii and O. Dopfer, J. Phys. Chem. B, 2015, 119, 1388-1406.

53 N. Solcà and O. Dopfer, Chem. Phys. Lett., 2001, 347, 59-64. 54 O. Couronne and A. Ellinger, Chem. Phys. Lett., 1999, 306, 71-77. 55 E. A. Colbourn and A. E. Douglas, J. Chem. Phys., 1976, 65, 1741-1745.

56 T. Ikeda, K. Sakota and H. Sekiya, J. Phys. Chem. A, 2016, 120, 1825-1832. 